\title{
Defoliation effects on reproductive biomass: Importance of scale and timing
}

\author{
MICHAEL T. ANDERSON AND DOUGLAS A. FRANK
}

Authors are a Graduate Student and an Assistant Professor in the Department of Biology, Biological Research Laboratories, Syracuse University, Syracuse, N.Y. 13244.

\begin{abstract}
Community-level (per unit area) and individual tiller reproductive biomass inside and outside of long-term exclosures on the northern winter range of Yellowstone National Park, USA were compared. Grazed areas had twice the number of reproductive tillers $\mathrm{m}^{-2}$ (186 compared to 88 tillers $\mathrm{m}^{-2}$ ), and greater total reproductive biomass $\mathrm{m}^{-2}$ than ungrazed plots $(13 \mathrm{com}$ pared to $7 \mathrm{~g} \mathrm{~m}^{-2}$ ). In contrast, seed number tiller-1 was greater for grasses in exclosures. Because of these offsetting responses, seed production (no. $\mathrm{m}^{-2}$ ) was unaffected by herbivores. On an area basis, grazed grasses allocated proportionally more biomass to reproduction (reproductive biomass/aboveground biomass) than ungrazed grasses. We propose that altered plant demography and morphology following defoliation explain how grazers might increase the allocation of biomass to reproduction in Yellowstone grasslands.

To understand these results in light of ecological and agronomic studies, we reviewed literature from 118 sources that reported the effects of defoliation on the production of reproductive biomass. The review suggested that the results of herbivory or defoliation on plant reproductive biomass depended on the scale of measurement (community vs. plant). In addition, timing of grazing or defoliation emerged as a key factor that determined whether sexual reproduction was inhibited. Like the early season grazing that is typical of Yellowstone's northern winter range, studies often showed that early season defoliation stimulated production of community-level reproductive biomass. Our results rectify disagreements in the literature that ultimately derive from differences in either timing of defoliation or measurement scale.
\end{abstract}

Key Words: grassland, ungulate, grazing, clipping, seed production and yield, Yellowstone National Park, literature review

Seed production can influence the structure, composition, and function of grassland ecosystems. Recruitment from seed facilitates colonization after disturbance, offsets mortality of individual plants in a community, and maintains genetic variability of

Research was funded by NSF grant \# D.E.B. 9726569 to D.F. The authors would like to thank J. Augustine for help with data collection and F. Ross and J. Whipple for help with plant identification. The paper benefited from discussions with M. Haferkamp, A.B. Frank, S. Heckathorn, D. Augustine, M. Sankaran, J. Ratnam, D. Burua, and from the comments of anonymous reviewers.

Manuscript accepted 15 Nov. 02.
Resumen

Se comparó la biomasa de tallos reproductivos a nivel individual y de comunidad (por unidad de área)dentro y fuera de exclusiones de largo plazo localizadas en un pastizal de invierno del norte del Parque Nacional Yellowstone, E.U.A. Las áreas apacentadas tuvieron el doble de hijuelos reproductivos $\mathrm{m}^{-2}(186$ contra 88 hijuelos $\mathrm{m}^{-2}$ ) y una mayor biomasa reproductiva $\mathrm{m}^{-2}$ que las parcelas sin apacentar $\left(13\right.$ versus $\left.7 \mathrm{~g}^{-2}\right)$. En contraste, el número de semillas por hijuelo-1 fue mayor en los zacates dentro de la exclusión. Debido a estas respuestas compensatorias, la producción de semilla (número $\mathrm{m}^{-2}$ ) no fue afectada por los herbívoros. En términos de área, los zacates apacentados destinaron proporcionalmente más biomasa a la reproducción (biomasa reproductiva/biomasa aérea) que los zacates sin apacentar. Proponemos que la demografía y morfología vegetal alterada después del apacentamiento explica como los apacentadores pueden incrementar la asignación de biomasa a la reproducción en los pastizales del Yellowstone. Para entender estos resultados a la luz de estudios ecológicos y agronómicos revisamos literatura de 118 fuentes que reportaron los efectos de la defoliación en la producción de biomasas reproductiva. La revisión sugiere que los resultados de la herviboría o defoliación en la biomasa reproductiva de la planta depende de la escala de medición (comunidad vs. planta). Además, la época de apacentamiento o defoliación surgió como un factor clave que determinó si la reproducción sexual fue inhibida. Como el apacentamiento a inicios de la estación es típico en los pastizales invernales del norte de Yellowstone, los estudios a menudo mostraron que la defoliación temprana estimulo la producción de biomasa reproductiva a nivel de comunidad. Nuestros resultados rectifican desacuerdos de la literatura que finalmente se derivan de diferencias tanto en el tiempo de defoliación o en la escala de medida.

populations, allowing them to adapt to environmental change. There are 2 disparate views of how large herbivores influence grassland seed production. To plant ecologists studying the effect of herbivory on fitness at the individual plant level, grazing should reduce carbon allocation to seed production. This generality seems to be well supported; defoliation reduces biomass of flowers, fruits, seeds, and reproductive tillers of individuals (for examples see Jameson 1963, Crawley 1983, Belsky 1986a, Maschinski and Whitham 1989, Whitham et al. 1991), with a few exceptions (Paige and Whitham 1987, Lennartsson et al. 1998). This viewpoint is reinforced by observations that grazing ecotypes of several grass species allocate less biomass to seed pro- 
duction than conspecific nongrazing ecotypes (Stapledon 1928, Kemp 1937, Hickey 1961, Detling and Painter 1983, Jaramillo and Detling 1988, Painter et al. 1993, Smith 1998).

In contrast, agricultural managers of seed crops, interested in seed yield per unit area, find that the response of grassland seed production to herbivory depends on the timing and intensity of defoliation. Several studies suggest that grazing does not decrease seed yield (Roberts 1958, 1965, Bean et al. 1979, Watson and Watson 1982, Hebblewaite and Clemence 1983, Winter and Thompson 1987, Conlan et al. 1994) and in many cases increases it (Sprague 1954, Day et al. 1968, Steiner and Grabe 1986, Sharrow and Motazedian 1987, Miller et al. 1993, Conlan et al. 1994, Young et al. 1996). In some studies, grazing or clipping increased the number of reproductive tillers per unit area (Herron 1976, Brown 1980), however this was not always followed by a corresponding increase in seed yield. Thus, the effect of defoliation on production of reproductive biomass is viewed differently by plant ecologists and agricultural managers. Plant ecologists tend to expect inhibition and agricultural researchers report neutral or even positive effects.

Approximately 2,000 elk (Cervus elaphus L.), 300-700 bison (Bison bison L.), and 600 pronghorn (Antilocarpa americana Ord.) graze the northern winter range of Yellowstone National Park from November-April each year (Singer and Mack 1993). Ungulates increase rates of plant production and nutrient cycling in Yellowstone grasslands (Frank et al. 1998, Frank and Groffman 1998). Moreover, comparisons of grasslands inside and outside long-term exclosures indicate that grazers have not significantly influenced grassland species composition (Houston 1982, Coughenour 1991, Singer 1995). Our objective was to determine how migratory native grazers influence seed production on the northern winter range of Yellowstone National Park.

\section{Materials and Methods}

\section{Site Description}

We sampled the effects of grazing on aboveground reproductive tiller numbers per plot, seed numbers per tiller and per plot, and allocation to reproductive versus vegetative biomass at the plot level. Field data were collected on the northern winter range of Yellowstone National Park, USA $\left(44^{\circ} 55^{\prime}\right.$ to $45^{\circ} 10^{\prime} \mathrm{N}$ and $110^{\circ} 10^{\prime}$ to $110^{\circ} 50^{\prime}$ W), from July 1999-Sep. 1999. Long-term effects of excluding ungulates on community level patterns of reproductive biomass allocation in grasses was studied by sampling grassland plots inside and outside of 5 exclosures erected between 1958 and 1962. Soils of the northern winter range are largely derived from andesitic and sedimentary glacial till that was deposited during the Pleistocene (Keefer 1987). The climate in the northern winter range is cool and dry; 15 year $95 \%$ confidence intervals for mean annual precipitation and temperature from 2 weather stations range from $33.7-38.6 \mathrm{~cm}($ mean $=36.1 \mathrm{~cm})$ and $4.6-5.3^{\circ} \mathrm{C}\left(\right.$ mean $\left.=4.9^{\circ} \mathrm{C}\right)$ at Mammoth $\left(44^{\circ} 59^{\prime} \mathrm{N} / 110^{\circ} 42^{\prime} \mathrm{W}\right)$ to $39.2-45.5 \mathrm{~cm}$ $($ mean $=42.3 \mathrm{~cm})$ and $1.7-2.4^{\circ} \mathrm{C}($ mean $\left.=2.1^{\circ} \mathrm{C}\right)$ at Tower $\left(44^{\circ} 55^{\prime} \mathrm{N} / 110^{\circ} 25^{\prime} \mathrm{W}\right)$ (NOAA 2001). Neither mean annual precipitation nor annual temperature in the year of our study was significantly different from the 15-year average at either weather station; 1999 annual precipitation and temperature was 34.8 and $43.2 \mathrm{~cm}$, and 5.2 and $1.8^{\circ} \mathrm{C}$, at Mammoth and Tower, respectively (Table 1 ).

Two treatments, fenced for $\sim 40$ years and unfenced, were replicated across the 5 sites. At each site, 2 paired grassland plots, 1 inside and 1 outside exclosures, approximately $100 \mathrm{~m}^{2}$ (usually $10 \times 10 \mathrm{~m}$ ) each, were chosen to minimize variation in slope, aspect, and water drainage. Dominant native grass species at the sites were Festuca idahoensis Elmer, Koeleria macrantha (Ledeb.) Schult., Poa secunda Presl., Pseudoroegneria spicata (Pursh) A. Love, and Hesperostipa comata (Trin. \& Rupr.) Barkworth. The non-native species Agropyron cristatum (L.) Gaertn. was dominant at 1 of the sites, but was equally abundant inside and outside of the exclosure. Less common grasses were Eremopyrum triticeum (Gaertn.) Nevski, Bromus sp., Danthonia sp., Achnatherum hymenoides (Roemer \& Schult.) Barkworth, Elymus elymoides (Raf.) Swezey, and Nassella viridula (Trin.) Barkworth. Common genera of forbs and shrubs were Artemisia, Achillea, Antennaria, Chrysothamnus, Cirsium, Crepis, Erigeron, Lupinus, Potentilla, Taraxacum, and Trifolium. The 3 most common grazers at the sites were elk, bison, and pronghorn. Descriptions of the 5 grassland sites, 2 at Stephen's Creek, 2 at Blacktail Plateau, and 1 at Junction Butte, are described in detail elsewhere (Houston 1982).

\section{Sampling Methods}

Within a plot, aboveground biomass, species richness, and the number of reproductive tillers on grasses were sub-sampled at 4 random locations. Aboveground grass biomass was estimated by clipping all live grass within one, $50 \times 50 \mathrm{~cm}$ quadrat at each of the 4 sub-sampling locations to ground level. Samples were then dried at $70^{\circ} \mathrm{C}$ for at least 2 days and weighed. Total aboveground live biomass and species composition were estimated by counting the number of vegetation contacts from 50 randomly located pins passed through a $50 \mathrm{~cm}$ high frame at a $53^{\circ}$ angle within each of the 4 sub-sampling locations. The number of pin contacts was used to estimate total aboveground biomass inside and outside exclosures using previously established regression equations for the herbaceous vegetation of Yellowstone (Frank and McNaughton 1990).

Grass reproductive tiller density was estimated by counting reproductive tillers within three, $50 \times 50 \mathrm{~cm}$ quadrats placed randomly within each of the 4 sub-sampling locations. From 1 of the 3 quadrats, all reproductive tillers were collected and dried for at least 2 days at $70^{\circ} \mathrm{C}$. Tillers were sorted by species, and then separated into stem and inflorescence. After drying,

Table 1. Mean annual precipitation and temperature from 2 weather stations on the northern winter range of Yellowstone National Park, Wyo., USA. Data are from 1999 (the year of our study) and the mean for the previous 15 years.

\begin{tabular}{|c|c|c|c|c|c|c|c|}
\hline $\begin{array}{l}\text { Weather } \\
\text { Station }\end{array}$ & Location & 1999 & $\begin{array}{c}\text { Precipitation } \\
15 \mathrm{yr} . \\
\text { mean }\end{array}$ & $\begin{array}{l}95 \% \text { confidence } \\
\text { interval for mean }\end{array}$ & $\begin{array}{l}15 \mathrm{yr} . \\
1999\end{array}$ & $\begin{array}{c}\text { Temperature } \\
95 \% \text { confidence } \\
\text { mean }\end{array}$ & interval for mean \\
\hline & & ------. & $(\mathrm{cm}$ & - & $-\cdots-\infty-$ & $\left({ }^{\circ} \mathrm{C}\right)$ & 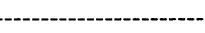 \\
\hline Mammoth & $44^{\circ} 59^{\prime} \mathrm{N} / 110^{\circ} 42^{\prime} \mathrm{W}$ & 34.8 & 36.1 & $33.7-38.6$ & 5.2 & 4.9 & $4.6-5.3$ \\
\hline Tower & $44^{\circ} 55^{\prime} \mathrm{N} / 110^{\circ} 25^{\prime} \mathrm{W}$ & 43.2 & 42.3 & $39.2-45.5$ & 1.8 & 2.1 & $1.7-2.4$ \\
\hline
\end{tabular}


stem and inflorescence mass was weighed and lengths were measured. As an index of seed number, we estimated the number of reproductive florets per tiller for grass each species. When the number of tillers in a sub-sample for a given species was > 10 , a random sample of 10 seed heads was selected and the florets were counted. The mean number of florets per tiller for the 10 seed heads was then multiplied by the number of tillers of each species to derive species-specific estimates of floret number per sub-sample. When sub-samples contained $\leq 10$ seed heads of a species, all florets were counted.

\section{Grass Demography}

As part of a separate study on spatial heterogeneity of Yellowstone grasslands, baseline data on grass density and size were collected at 1 exclosure from Steven's Creek and Blacktail. Data were also collected at Lamar, at which grass reproductive biomass was not measured, but is similar in grazing, precipitation, and species composition to Junction Butte. A grid of 80 evenly spaced points $(8 \times 10)$ was established inside and outside of each of the 3 exclosures. At each point, the distance to the center of the nearest grass and the basal lengths of 2 perpendicular axes of the nearest individual were measured. Plant density ( $D$, plants $\left.\mathrm{m}^{-2}\right)$ was estimated by the nearest individual method, $\mathrm{D}=1$ / $\left(\mathrm{k}^{*} \mathrm{~L}\right)^{2}$, where the method correction factor $\mathrm{k}=2$ and $\mathrm{L}$ is the average distance (in $\mathrm{m}$ ) to the nearest plant for each grid (Cottam and Curtis 1956). Plant size was estimated by calculating elliptical basal area $\left(\mathrm{cm}^{2}\right)$ from the lengths of the 2 axes for each individual.

\section{Data analysis}

Tiller density is reported per unit area (no. $\mathrm{m}^{-2}$ ), while floret number and tiller biomass components (inflorescence, stem, and total) are reported per unit area (no. $\mathrm{m}^{-2}$ and grams $\mathrm{m}^{-2}$ ) and per tiller (no. tiller ${ }^{-1}$ and grams tiller ${ }^{-1}$ ). Data presented per plot represent the mean community response to a treatment. Data per tiller were averaged by tiller within a sub-sample and then averaged within a plot to calculate a tillerbased mean. Data per plot are summed within a sub-sample and then averaged within a plot to calculate a plot mean. Finally, to determine the effects of excluding grazers on community level patterns of biomass allocation, we compared reproductive biomass per unit of aboveground biomass (the ratio inflorescence biomass:plot aboveground biomass) between treatments with a Wilcoxon matched pair test.
Grazer effects were determined with paired t-tests, with sites as replicates, when differences between paired treatment means were normally distributed (determined with a Shapiro - Wilks' W test; $\mathrm{P}>0.05$ ). When differences were not normally distributed, data were analyzed with a Wilcoxon matched pair test. Because of small sample sizes, all P-values $<0.10$ were considered significant. All statistical analyses were performed in Statistica release 5 (1998).

\section{Literature Review}

We summarized published literature that reported effects of grazing, clipping, or seed removal on seed yields or plant reproductive biomass. The primary literature was searched with online databases such as Agricola and Cambridge Scientific Abstracts, using keywords such as "defoliation", "grazing", "clipping”, "reproduction", "seeds", etc. Our main objective was to compile data sets that allowed quantitative assessment of how plant tissue removal influenced plant reproductive biomass at 2 scales, whole plots and individual plants, from as ecologically diverse sources as possible. Therefore, studies of all natural defoliators or seed predators (insects, birds, etc.) were included. Moreover, we included studies that reported grazer effects on soil seed banks and studies where populations of plants with different grazing histories were compared. Studies were hierarchically grouped by the spatial scale of measurement (individual plant or whole plot), by broad functional group (graminoids or non-graminoids), by the method of defoliation (clipping or grazing), and by identity of defoliator (insect or ungulate). Within each category, we listed all plant species for which data were presented and assessed the effects of defoliation on reproductive biomass as reported by the authors. Results were reported as positive $(+)$, negative $(-)$, or no difference $(0)$ among defoliation and control treatments. Studies in which the timing of defoliation relative to anthesis was manipulated commonly had early, intermediate, or late defoliation treatments. Biomass removal well before the initiation of flowering (i.e. before internode elongation for grasses) was classified as early, several weeks prior to flowering was classified as intermediate (i.e. boot stage for grasses), and at or later than the initiation of flowering was classified as late. Defoliation was categorized as intermediate when information on the timing of defoliation relative to flowering was not provided. Results from studies that include the effects of the severity of defoliation are also reported.

\section{Results}

\section{Yellowstone National Park Study}

Grazing did not affect species richness $\left(t_{4}=0.848 ; P=0.44\right)$. The mean $( \pm S E)$ percentage similarity of species composition inside and outside of exclosures was $70.5 \%( \pm 1.3)$ and ranged from 67.0 to $74.4 \%$ across the 5 sites. Total aboveground biomass was unaffected by grazers $\left(\mathrm{t}_{4}=1.185, \mathrm{P}=0.30\right.$; Table 2$)$, as was aboveground grass biomass $\left(\mathrm{t}_{4}=1.269, \mathrm{P}\right.$ $=0.273$; Table 2). However, grazing resulted in a nearly doubling of the number of reproductive grass tillers per plot $\left(\mathrm{t}_{4}\right.$ $=3.542, \mathrm{P}=0.024$; Table 2). Likewise, grazed plots had greater total reproductive tiller biomass per area $\left(\mathrm{Z}_{4}=2.023 ; \mathrm{P}=\right.$ 0.043 ), which was caused by both greater total inflorescence $\left(\mathrm{Z}_{4}=2.023 ; \mathrm{P}=0.043\right)$ and total stem weights $\left(\mathrm{t}_{4}=2.210 ; \mathrm{P}=\right.$ $0.091)$. However, on a per tiller basis, neither reproductive tiller mass $\left(\mathrm{t}_{4}=1.624 ; \mathrm{P}\right.$ $=0.180)$ nor the inflorescence mass $\left(t_{4}=\right.$ $1.190 ; \mathrm{P}=0.300$ ) differed between grazed and ungrazed plots (Table 2). Thus, increased reproductive tiller mass per plot in grazed areas was caused by an increase in reproductive tiller number, rather than by greater individual tiller mass.

On a per tiller basis, florets were more numerous on tillers that were excluded from grazers $\left(Z_{4}=1.753 ; \mathrm{P}=0.078\right)$. However, the total number of florets per plot was unaffected by grazing $\left(\mathrm{t}_{4}=1.392\right.$, $P=0.236$ ), as a result of the greater number of reproductive tillers per area in grazed plots. Reproductive tiller length was greater in ungrazed areas $\left(Z_{4}=2.023\right.$; $\mathrm{P}=0.043$ ); this was attributed to differences in both stem length $\left(Z_{4}=2.023 ; \mathrm{P}=\right.$ $0.043)$ and inflorescence length $\left(\mathrm{t}_{4}=\right.$ 2.949; $\mathrm{P}=0.042$ ).

Defoliated plants allocated significantly more biomass to reproduction per unit of standing biomass than did plants in ungrazed plots $\left(\mathrm{Z}_{4}=2.03, \mathrm{P}=0.043\right.$, Table 2). Whether or not grazers also increased the ratio of reproductive to aboveground biomass after accounting for foliage removed by herbivores early in the growing season cannot be determined from this study, nor has it been addressed in any study of which we are aware.

Few significant differences exist between grazed and ungrazed dominant native plants when data are analyzed on a species-specific basis (Table 3 ). Only $P$. spicata had significantly more reproduc- 
Table 2. Mean \pm 1 S.E. values for vegetation characteristics on a per area and per tiller basis for grazed and ungrazed plots in Yellowstone National Park. Associated P-values from statistical analyses (either paired t-test or Wilcoxon matched pair test) tested for effects of grazing. Total reproductive biomass $=$ stem + inflorescence .

\begin{tabular}{|c|c|c|c|}
\hline Variable & $\begin{array}{l}\text { Ungrazed } \\
\text { mean } \pm \mathrm{SE}\end{array}$ & $\begin{array}{c}\text { Grazed } \\
\text { mean } \pm S E\end{array}$ & P-value \\
\hline & \multicolumn{3}{|c|}{ 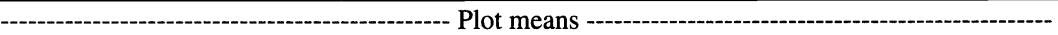 } \\
\hline Total aboveground live biomass $\left(\mathrm{g} \mathrm{m}^{-2}\right)$ & $71.2 \pm 8.6$ & $64.6 \pm 7$ & 0.30 \\
\hline Aboveground live grass biomass $\left(\mathrm{g} \mathrm{m}^{-2}\right)$ & $34.8 \pm 5.5$ & $28.8 \pm$ & 0.27 \\
\hline Reproductive tiller density (no. $\mathrm{m}^{-2}$ ) & $87.8 \pm 16.2$ & $186.4 \pm 31.3$ & $0.02 *$ \\
\hline Inflorescence biomass per plot $\left(\mathrm{g} \mathrm{m}^{-2}\right)$ & $1.5 \pm 0.5$ & $3.4 \pm 1.4$ & $0.04 *$ \\
\hline Reproductive stem biomass per plot $\left(\mathrm{g} \mathrm{m}^{-2}\right)$ & $5.4 \pm$ & $9.2 \pm$ & 0.09 \\
\hline Total reproductive biomass per plot $\left(\mathrm{g} \mathrm{m}^{-2}\right)$ & $6.8 \pm$ & $12.6 \pm 4.1$ & $0.04 *$ \\
\hline Number florets per plot (no. $\left.\mathrm{m}^{-2}\right)$ & $2,944 \pm 485$ & $4,348 \pm 954$ & 0.24 \\
\hline Reproductive : aboveground biomass ratio & $0.26 \pm 0.12$ & $0.53 \pm 0.25$ & $0.04 *$ \\
\hline Inflorescence biomass per tiller ( $\mathrm{g}$ tiller $\left.{ }^{-1}\right)$ & $0.02 \pm$ & $\begin{array}{l}\text { - Tiller means - } \\
0.02 \pm 0.01\end{array}$ & 0.30 \\
\hline Reproductive stem biomass per tiller ( g tiller $^{-1}$ ) & $0.07 \pm 0.02$ & $0.05 \pm$ & 0.17 \\
\hline Total reproductive biomass per tiller $\left(\mathrm{g}_{\text {tiller }}{ }^{-1}\right)$ & $0.10 \pm 0.03$ & $0.07 \pm$ & 0.18 \\
\hline Number florets per tiller (no. tiller ${ }^{-1}$ ) & $41.9 \pm 7.7$ & $24.1 \pm 4.8$ & 0.08 \\
\hline Reproductive tiller stem length (mm) & $257.1 \pm 8.8$ & $207.7 \pm 13.5$ & 0.04* \\
\hline Reproductive tiller inflorescence length (mm) & $54.1 \pm 4.5$ & $42.5 \pm 3.7$ & 0.04* \\
\hline
\end{tabular}

*Treatment means significantly different at $\mathrm{P}<0.05$

Bold type indicates treatment means significantly at $\mathrm{P}<0.10$

tive tillers per plot $\left(\mathrm{t}_{4}=3.553, \mathrm{P}=0.038\right)$ and greater ratio of tillers to aboveground biomass $\left(\mathrm{t}_{4}=2.740, \mathrm{P}=0.071\right)$ in grazed compared to ungrazed plots. Likewise, estimates for reproductive tiller mass and length are statistically greater only for $K$. macrantha $\left(\mathrm{t}_{4}=5.772, \mathrm{P}=0.010\right)$. Thus, even though mean estimates of reproduction are not different for grazed and ungrazed dominant grasses, the effect of defoliation on reproductive biomass clear- ly emerges when plant responses are analyzed at the community level (Table 2).

Basal areas of grasses were smaller in grazed compared with ungrazed plots, suggesting that previous grazing reduced plant size (inside mean $=7.1 \mathrm{~cm}^{2}$, outside mean $=3.7 \mathrm{~cm}^{2}, \mathrm{t}_{2}=7.07 ; \mathrm{P}=.02$, from $\mathrm{a}$ paired t-test for a difference in $\log _{\mathrm{e}}$ transformed mean basal area, Table 4). Grass tiller densities were greater in grazed than ungrazed plots at all 3 sites measured (inside mean $=56.6$ tillers $\mathrm{m}^{-2}$, outside mean $=110.3$ tillers $\mathrm{m}^{-2}$, Table 4 ).

\section{Literature Review}

We identified 118 articles that reported the effects of defoliation on reproductive biomass of 115 plant species from 88 genera (Appendix 1). Taxonomic references and authorities in Appendix 1 follow directly from the original studies; authori-

Table 3. Mean aboveground biomass and tiller characteristics of 4 dominant grass species inside (UG) and outside (G) herbivore exclosures at 5 sites in Yellowstone National Park. $\mathbf{P}=\mathbf{P}$-value from a paired $t$-test. Sample sizes are reported in parentheses next to species names.

\begin{tabular}{|c|c|c|c|c|c|c|c|c|c|c|c|c|}
\hline & \multicolumn{12}{|c|}{ Species } \\
\hline & \multicolumn{3}{|c|}{$\begin{array}{c}\text { Festuca } \\
\text { Idahoensis (3) }\end{array}$} & \multicolumn{3}{|c|}{$\begin{array}{c}\text { Koeleria } \\
\text { macrantha }(4)\end{array}$} & \multicolumn{3}{|c|}{$\begin{array}{c}\text { Poa } \\
\text { secunda (5) }\end{array}$} & \multicolumn{3}{|c|}{$\begin{array}{l}\text { Psudoregnaria } \\
\text { spicata (4) }\end{array}$} \\
\hline & UG & G & $\mathrm{P}$ & UG & G & $\mathrm{P}$ & UG & $\mathrm{G}$ & $\mathrm{P}$ & UG & $\mathrm{G}$ & $\mathrm{P}$ \\
\hline $\begin{array}{l}\text { Aboveground } \\
\text { live biomass } \\
\left(\mathrm{g} \mathrm{m}^{-2}\right)\end{array}$ & 31.2 & 20.5 & 0.29 & 9.1 & 14.3 & 0.36 & 1.7 & 2 & 0.51 & 14.3 & 20.2 & 0.14 \\
\hline $\begin{array}{l}\text { Reproductive } \\
\text { tiller density } \\
\left(\text { no. } \mathrm{m}^{-2}\right)\end{array}$ & 57.4 & 72.8 & 0.37 & 22.7 & 53.3 & 0.14 & 6.8 & 9.2 & 0.55 & 15.4 & 45.8 & $0.04 *$ \\
\hline $\begin{array}{l}\text { Tillers per } \\
\text { gram biomass } \\
\left(\text { no. } \mathrm{m}^{-2} \mathrm{~g}^{-1}\right)\end{array}$ & 1.8 & 3.8 & 0.15 & 3.4 & 3.9 & 0.82 & 3.9 & 4.3 & 0.83 & 0.9 & 2.3 & 0.07 \\
\hline $\begin{array}{l}\text { Total reproductive } \\
\text { biomass per tiller } \\
\left(\mathrm{g} \mathrm{tiller}^{-1}\right)\end{array}$ & 0.04 & 0.02 & 0.24 & 0.06 & 0.04 & 0.09 & 0.03 & 0.04 & 0.21 & 0.13 & 0.09 & 0.31 \\
\hline $\begin{array}{l}\text { Total reproductive } \\
\text { tiller length } \\
(\mathrm{mm})\end{array}$ & 340.5 & 267.4 & 0.15 & 250.4 & 209 & 0.01* & 219.1 & 240.9 & 0.53 & 386.9 & 302.4 & 0.20 \\
\hline $\begin{array}{l}\text { Number florets } \\
\text { per tiller } \\
\text { (no. tiller }{ }^{-1} \text { ) }\end{array}$ & 8.7 & 9.1 & 0.77 & 79.1 & 74.4 & 0.45 & 25.7 & 24.1 & 0.76 & 4.9 & 5.2 & 0.37 \\
\hline
\end{tabular}

*Treatment means significantly different at $\mathrm{P}<0.05$

Bold type indicates treatment means significantly at $\mathrm{P}<0.10$ 
Table 4. Grass sizes and densities for grasses measured inside and outside of 3 Yellowstone National Park exclosures. Values represent means from data collected from the nearest individuals to each point in an $8 \times 10$ grid.

\begin{tabular}{lcc}
\hline \hline Site & $\begin{array}{c}\text { Ungrazed } \\
\text { mean } \pm \text { SE }\end{array}$ & $\begin{array}{c}\text { Grazed } \\
\text { mean } \pm \text { SE }\end{array}$ \\
\hline Lamar & ----- & Plant basal area $\left(\mathrm{cm}^{2}\right)------$ \\
Blacktail & 3.1 & 1.9 \\
Steven's Creek & 6.8 & 3.1 \\
& 11.2 & 6.2 \\
& ---- Plant density & $\left(\right.$ no. $\left.^{-2}\right)$---- \\
Lamar & 59.6 & 184.7 \\
Blacktail & 83.2 & 113 \\
Steven's Creek & 26.9 & 33.3 \\
\hline
\end{tabular}

ties are not presented if not provided in the original paper. Investigations examined individual plant traits $(n=73)$, whole plot effects $(n=50)$, or both $(n=3)$. Whole plot studies included data for 39 plant species, 30 of which were grasses or sedges. Graminoids were disproportionately represented in whole plot studies because of their agronomic importance and the tendency for crop biomass to be measured per unit area. Likewise, 5 of the remaining 10 forbs were crop or forage species. The 84 species included in studies of individual plants were more evenly distributed between graminoids $(n=36)$ and forbs $(n=48)$.
Where data were collected at the plot level, the previous studies showed that early defoliation stimulated reproductive biomass in $33 \%$, had no effect in $56 \%$, and reduced it in $11 \%$ of the cases. For plotlevel studies, intermediately timed defoliation stimulated reproductive biomass in $11 \%$ of the cases, had no effect in $36 \%$, and decreased reproductive biomass in $52 \%$ of the 85 cases. For late defoliation treatments measured at the whole plot, reproductive biomass was stimulated in only $8 \%$ of the cases, was unaffected in $21 \%$, and reduced in $71 \%$ of the 71 cases. In all, over half the studies that measured the effects of defoliation on reproductive biomass per unit area reported either no effect $(37 \%)$ or a stimulatory effect $(16 \%)$ of defoliation (Table 5). This was the case for both graminoids and non-graminoid species, but a lower percentage of nongraminoids increased reproductive biomass after defoliation (11 compared to 18\%; Table 5). For whole-plot studies, similar percentages of negative effects from defoliation were reported for graminoids $(47 \%)$ and non-graminoids (45\%).

For individual plants, of the 19 studies that included an early defoliation treatment, $16 \%$ reported an increase in reproductive biomass, $42 \%$ reported no effect, and $42 \%$ reported a negative effect. For both studies in which the timing of seed removal was controlled, early removal increased seed production. For the 122 individual plant studies with a single defoliation of intermediate timing, reproductive biomass increased in $10 \%$, was unaffected in $39 \%$, and decreased in $51 \%$ cases. In the 29 individual plant studies that included a late defoliation treatment, reproductive biomass was not stimulated in any case, but was unaffected in $17 \%$, and negatively affected in $83 \%$. Compared to whole-plot studies, a greater percentage of individual plant studies reported negative effects of defoliation (55 compared to 47\%). Graminoids and non-graminoids from individual plant studies contributed roughly equally to this result; 55 and $56 \%$ of the graminoid and non-graminoid studies, respectively, reported a decrease subsequent to defoliation.

To compare the effects of defoliation on reproductive biomass of cool-season with warm-season grasses, graminoid studies that reported the effects of clipping or grazing were grouped according to photosynthetic pathway $\left(C_{3}\right.$ or $\left.C_{4}\right)$. The percentage of studies reporting positive, negative, and no effects were determined for whole-plot studies, individual plant studies, and the 2 combined (Table 6). When timing treatments and study scales were combined, defoliation reduced reproductive biomass of $\mathrm{C}_{4}$ grasses in more cases than for $\mathrm{C}_{3}$ grasses $(67 \%$ compared to $47 \%$ ). Reproductive biomass of $\mathrm{C}_{4}$ grasses was rarely stimulated by defoliation $(2 \%$

Table 5. Results from 118 studies that measured the effect of defoliation on vegetation reproductive biomass or number of reproductive structures. Table values represent the percentage of $n$ studies that report positive $(+)$, no $(0)$, or negative $(-)$ effects of defoliation on the production of reproductive biomass or number or reproductive structures. Studies are separated by early, intermediate, and late defoliation treatments and grouped hierarchically by study scale (whole-plot or individual plant), vegetation type (graminoids or non-graminoids), and type of defoliation (see text). Totals in the last column are the combined results of early, intermediate, and late treatments. See Appendix 1 for the studies used to generate table values.

\begin{tabular}{|c|c|c|c|c|c|c|c|c|c|c|c|c|c|c|c|c|}
\hline & \multicolumn{16}{|c|}{ Timing } \\
\hline & \multicolumn{4}{|c|}{ Early } & \multicolumn{4}{|c|}{ Intermediate } & \multicolumn{4}{|c|}{ Late } & \multicolumn{4}{|c|}{ Total } \\
\hline & $\mathrm{n}$ & - & 0 & + & $\mathrm{n}$ & - & 0 & + & $\mathrm{n}$ & - & 0 & + & $\mathrm{n}$ & - & 0 & + \\
\hline Whole-plot & 64 & 11 & 56 & 33 & 88 & 52 & 36 & 11 & 73 & 71 & 21 & 8 & 225 & 47 & 37 & 16 \\
\hline Graminoids & 47 & 11 & 49 & 40 & 69 & 51 & 38 & 12 & 54 & 74 & 19 & 7 & 170 & 47 & 35 & 18 \\
\hline Grazing & 12 & 17 & 50 & 33 & 15 & 67 & 20 & 13 & 14 & 57 & 29 & 14 & 41 & 49 & 32 & 20 \\
\hline Cutting & 35 & 9 & 49 & 43 & 54 & 46 & 43 & 11 & 40 & 80 & 15 & 5 & 129 & 47 & 36 & 18 \\
\hline Non-graminoids & 17 & 12 & 76 & 12 & 19 & 58 & 32 & 11 & 19 & 63 & 26 & 11 & 55 & 45 & 44 & 11 \\
\hline Grazing & 5 & 40 & 60 & 0 & 7 & 43 & 29 & 29 & 7 & 29 & 43 & 29 & 19 & 37 & 42 & 21 \\
\hline Cutting & 12 & 0 & 83 & 17 & 12 & 67 & 33 & 0 & 12 & 83 & 17 & 0 & 36 & 50 & 44 & 6 \\
\hline Individual plant & 19 & 42 & 42 & 16 & 122 & 51 & 39 & 10 & 29 & 83 & 17 & 0 & 170 & 55 & 36 & 9 \\
\hline Graminoids & 13 & 46 & 31 & 23 & 62 & 45 & 50 & 5 & 22 & 86 & 14 & 0 & 97 & 55 & 39 & 6 \\
\hline Grazing & & & & & 6 & 0 & 83 & 17 & & & & & 6 & 0 & 83 & 17 \\
\hline Clipping & 11 & 55 & 36 & 9 & 41 & 56 & 41 & 2 & 20 & 90 & 10 & 0 & 72 & 65 & 32 & 3 \\
\hline Transplants & & & & & 13 & 38 & 62 & 0 & & & & & 13 & 38 & 62 & 0 \\
\hline Seed removal & 2 & 0 & 0 & 100 & 2 & 50 & 0 & 50 & 2 & 50 & 50 & 0 & 6 & 33 & 17 & 50 \\
\hline Non-graminoids & 6 & 33 & 67 & 0 & 60 & 57 & 28 & 15 & 7 & 71 & 29 & 0 & 73 & 56 & 32 & 12 \\
\hline Insects & 1 & 0 & 100 & 0 & 16 & 69 & 19 & 13 & 1 & 100 & 0 & 0 & 18 & 67 & 22 & 11 \\
\hline Grazers & & & & & 12 & 25 & 50 & 25 & & & & & 12 & 25 & 50 & 25 \\
\hline Clipping & 5 & 40 & 60 & 0 & 32 & 63 & 25 & 13 & 6 & 67 & 33 & 0 & 43 & 60 & 30 & 9 \\
\hline
\end{tabular}


Table 6. Results from 38 whole-plot and 27 individual plant studies that measured the effect of grazing or clipping (transplants and seed removals are not included) on reproductive biomass for $C_{3}$ and $C_{4}$ graminiods. Table values represent the percentage of $n$ studies that report positive (+), no ( 0 ), or negative (-) effects of defoliation on the production of reproductive biomass or number or reproductive structures. Studies are separated by early, intermediate, and late defoliation treatments. All studies represent the result of whole-plot and individual plant studies combined. Totals in the last column are percentages for the sum of early, intermediate, and late treatments. See Appendix 1 for the studies used to generate table values.

\begin{tabular}{|c|c|c|c|c|c|c|c|c|c|c|c|c|c|c|c|c|}
\hline & & & & & & & & $\operatorname{ming}$ & & & & & & & & \\
\hline & & & & & & term & & & & & & & & & & \\
\hline & $\mathrm{n}$ & - & 0 & + & $\mathrm{n}$ & - & 0 & + & $\mathrm{n}$ & - & 0 & + & $\mathrm{n}$ & - & 0 & + \\
\hline $\mathrm{C}_{3}$ grasses & & & & & & & & & & & & & & & & \\
\hline All studies & 50 & 14 & 48 & 38 & 77 & 49 & 40 & 10 & 54 & 74 & 19 & 7 & 181 & 47 & 36 & 17 \\
\hline Whole-plot & 46 & 11 & 50 & 39 & 56 & 54 & 34 & 13 & 48 & 71 & 21 & 8 & 150 & 46 & 35 & 19 \\
\hline Individual plant & 4 & 50 & 25 & 2 & 21 & 38 & 57 & 5 & 6 & 100 & 0 & 0 & 31 & 52 & 42 & 6 \\
\hline $\mathrm{C}_{4}$ grasses & & & & & & & & & & & & & & & & \\
\hline All studies & 8 & 50 & 38 & 13 & 35 & 60 & 40 & 0 & 15 & 93 & 7 & 0 & 58 & 67 & 31 & 2 \\
\hline Whole-plot & 1 & 0 & 0 & 100 & 11 & 45 & 55 & 0 & 4 & 100 & 0 & 0 & 16 & 56 & 38 & 6 \\
\hline Individual plant & 7 & 57 & 43 & 0 & 24 & 67 & 33 & 0 & 11 & 91 & 9 & 0 & 42 & 71 & 29 & 0 \\
\hline
\end{tabular}

of the cases), while a moderate percentage of studies reported some stimulatory effect for $\mathrm{C}_{3}$ grasses $(17 \%$ of the cases). For both study scales, the results of summing early, intermediate, and late defoliation treatments produced similar trends; $\mathrm{C}_{4}$ grasses respond more negatively to defoliation than do $\mathrm{C}_{3}$ grasses. Individual plant studies of $\mathrm{C}_{4}$ grasses reported more negative responses $(71 \%)$ compared to $\mathrm{C}_{3}$ grasses $(52 \%)$, and out of 42 cases no stimulatory effects were reported for the $\mathrm{C}_{4}$ species. Likewise, at the whole-plot scale, $19 \%$ of $\mathrm{C}_{3}$ studies reported an increase in reproductive biomass subsequent to defoliation, while stimulatory effects were reported in only $6 \%$ of the $C_{4}$ studies. This was a result of the strong negative response of $\mathrm{C}_{4}$ grasses to intermediate and late defoliation treatments, which was reported in $60 \%$ and $93 \%$ of the studies respectively (Table 6).

In general, stimulation of reproductive biomass in individual plant studies was usually associated with morphological changes such as increased number of branches or basal rosettes leading to greater flower and fruit production without an associated decrease in seed number, weight, or viability. Stimulatory effects of defoliation were not reported in any of the studies that compared the response of grasses with variable grazing history. Historically grazed grass populations had equal or lower reproductive to vegetative biomass ratios than conspecifics from historically ungrazed sites.

\section{Discussion}

Early season grazing on the northern winter range of Yellowstone Park more than doubled the number of reproductive tillers per unit area across sites, despite similar aboveground biomass and vegetation cover inside and outside of exclosures at peak biomass. Correspondingly, the inflorescence mass per unit area was over twice as great in grazed compared with ungrazed plots. Stimulation of community level reproductive biomass by grazing is consistent with reports from agricultural systems. However, our results from Yellowstone are inconsistent with findings from other natural grassland systems (McNaughton 1979, O'Connor and Pickett
1992), where grazers directly consumed seed heads and reduce seed production. In the northern winter range of Yellowstone, migratory herds of elk and bison graze newly emerging vegetation early in the growing season, usually in April and May, then move off the sites. The seasonal pattern of grazing in Yellowstone's northern winter range matches management strategies developed to reduce removal of reproductive meristematic tissue and increase seed yield in agricultural systems (Young et al. 1996).

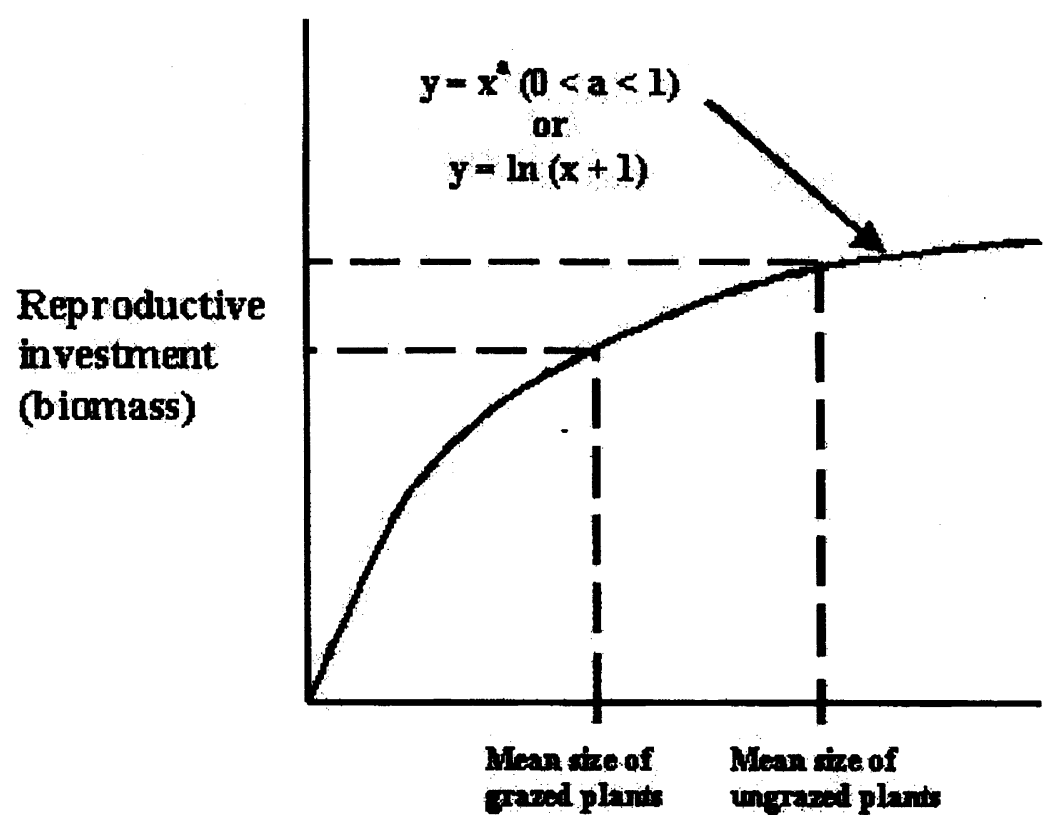

Fig. 1. The proposed function between mean plant size and investment in reproductive biomass for grasses in Yellowstone National Park. The saturating curve, along with evidence that mean plant size is smaller and density greater in grazed Yellowstone grassland, may explain the greater proportional reproductive biomass $\mathrm{m}^{-2}$ identified in our grazed plots. 
Grazer mediated changes in plant species composition, implicated in other seed production or seed bank studies (Jones 1968, Kinucan and Smeins 1992, O'Connor and Pickett 1992, Willms and Quinton 1995), are not likely to explain the results from Yellowstone grasslands. First, species similarity measures between treatments were high. In addition, species found in different proportions inside and outside of exclosures at 1 site were often found at inverse proportions at another site; this lowered percentage similarity between treatments but also argues strongly against differences in reproductive biomass across exclosures resulting from an artifact of species compositional differences. Finally, prior studies have found no differences in species composition between communities inside and outside of the Yellowstone exclosures (Houston 1982, Coughenour 1991, Singer 1995, Stolgren et al. 1999, Augustine and Frank 2001).

The increase in reproductive tiller density by grazers is consistent with the phenomenon of herbivory increasing vegetative tillering in a number of grasses (Jewiss 1972, Detling and Painter 1983, Belsky 1986b). However, reductions in floret number per tiller in grazed plots suggests that defoliation may have an inhibitory effect per plant, but a stimulatory effect when plants are measured per unit area. A potential explanation might be the general relationship between reproductive output and plant size and the effects of grazers on reducing plant size and increasing plant density. In addition to this study, large herbivores reduced bunchgrass basal size in several grasslands (Hickey 1961, Butler and Briske 1988, Pfeiffer and Hartnett 1995). Thus, if a positive saturating function of reproductive investment on plant size exists for Yellowstone grasses (Fig. 1), such as has been described for plants elsewhere (Crawley 1983), smaller plants that result from grazing might invest relatively more in reproductive growth. In addition to influencing plant size, 2 lines of evidence suggest that plant density differed between grazed and ungrazed plots. First, grass tiller density was greater in grazed plots for the 3 sites measured. Second, that biomass was not statistically different inside and outside exclosures, but grazed plants were smaller, further suggests plant density was greater in grazed plots. Therefore, the stimulation of reproductive biomass observed in plots in our study may be the result of grazers promoting more dense populations of smaller individuals that allocated proportionally more to reproduction than ungrazed grasses.
Thus, the stimulation of reproductive biomass subsequent to defoliation may result from 2 different mechanisms, which may be identifiable at different scales. 1) Reproductive biomass per individual is increased because plants allocate more biomass to reproduction after defoliation; this mechanism could be identified in studies of individual plants. 2) Reproductive biomass per individual is reduced or unaffected, but since plants are smaller and more dense per unit area, community-level reproductive biomass is greater subsequent to defoliation; this mechanism could be identified in whole-plot studies. Both mechanisms will be influenced by the phenological stage of vegetation at the time of defoliation, but the latter less so because a community-level stimulatory effect can result even if reproduction per individual is decreased. In addition, precipitation, and more importantly soil water, will influence phenological stage and the capacity for regrowth after grazing.

The literature clearly demonstrates that the timing of grazing is of critical importance to the production of reproductive biomass in many of the studies that we reviewed. The grazing of leaf material before internode expansion does not result in the removal of apical meristems and thus regrowth can ensue if soil water is adequate, whereas grazing after internode elongation may remove terminal meristems of developing floral buds (Jewiss 1972). Thus, timing and intensity of grazing in natural systems determines the outcome of grazing on reproductive tiller number and seed yield (Young et al. 1996, O'Connor and Pickett 1992). Hebblethwaite and Clemence (1983) reported that if grazing of perennial ryegrass (Lolium perenne L.) ceased before spiklet initiation, seed yield was not affected; if grazing continued after the initiation of spiklets, seed yield was greatly depressed. Similar results have been reported for tall fescue (Festuca arundinacea Schreb.) (Watson and Watson 1982), spring oats (Avena sp.) (Morris and Gardner 1958, Gardner and Wiggins 1960) and wheat (Triticum aestivum L.) (Finnell 1929, Aldrich 1959, Winter and Thompson 1987).

In addition to the importance of phenological stage controlling the response of plants to grazing, environmental factors may interact with timing of herbivory. Microclimatic conditions conducive for regrowth often vary over the growing season. For example, in western U.S. rangelands, where soil water typically declines throughout the growing season, plants may not be able to recover if grazed late in the season when precipitation has little influence on regowth (Sneva 1977). Thus, phenology and growth conditions probably both play roles in the allocation to reproductive tissue by grazed plants.

Whether or not smaller, denser plants, that allocate relatively more to reproduction, explain increases in reproductive biomass in the previous studies is not known. Herbivory increases plant density in some natural communities (i.e. Crawley 1983), yet the generality of this response has not emerged from the literature. Alternatively, defoliation may increase reproductive biomass per plant, without an associated change in plant density. For example, Young et al. (1996) reported that grazing stimulated reproductive tiller production per unit area with no difference in plant density between grazed and control plots, suggesting that it was the phenological stage at the time of defoliation that was more important than density in their study. Additionally, results from agricultural studies usually reflect short-term grazing treatments rather than the longer time periods that may be necessary to produce differences in plant density. Thus, in studies that measure the influence of short-term defoliation, on the scale of seasons, the phenological stage of vegetation is likely more important than population level effects such as plant density. The results from studies that measured reproductive biomass at either of 2 scales, whole-plot and individual plant level, are complex but seem to suggest whole plot studies report stimulatory effects more often than individual studies. This suggests population level effects that lead to greater reproductive biomass per area, such as increased densities of smaller individuals with higher fecundity, might be implicated in at least some cases. Another possibility is that plant defoliation is less severe in whole-plot studies than in individual plant studies. Most of the individual plant studies reviewed were clipped as opposed to grazed, and previous research suggests that clipping to simulate grazing results in more severe defoliation than does actual grazing (Hart and Balla 1982).

Our review of the literature suggests that, in terms of sexually reproductive biomass, $\mathrm{C}_{4}$ plants exhibit a more negative response to defoliation than do $\mathrm{C}_{3}$ plants. This finding is intriguing because, in general, $\mathrm{C}_{4}$ plants are more grazing tolerant than their $\mathrm{C}_{3}$ counterparts (Heckathorn et al. 1999). It is not known why $\mathrm{C}_{4}$ plants are more grazing tolerant than $\mathrm{C}_{3}$ plants, or why defoliation suppresses sexually reproductive tissues during regrowth, 
however, physiological differences and different environmental conditions may be responsible. For example, $\mathrm{C}_{4}$ plants have higher water and nutrient use efficiencies and maximum rates of photosynthesis, which may favor reallocation of biomass for vegetative versus sexual reproduction (Heckathorn et al. 1999). On the other hand, $\mathrm{C}_{3}$ and $\mathrm{C}_{4}$ plants vary in their distribution across rainfall and temperature gradients (e.g. Epstein et al. 1997 for the U.S. Great Plains). Growth conditions of $\mathrm{C}_{4}$ may, on average, favor greater allocation to leaves and roots after defoliation and less to sexual reproduction. However, the relative importance of physiology and environment in producing different responses of $C_{3}$ and $C_{4}$ grasses to defoliation requires specific testing.

Our study was designed to address both community level and individual plant level effect of grazing on seed production of grasslands in Yellowstone National Park. We found that early season grazing leads to greater numbers of reproductive tillers per unit area and did not decrease seed yield per unit area. We suggest that grazing in Yellowstone's Northern winter range maintains populations of smaller, denser grasses that, if grazed early, produce (per unit area) more reproductive tillers, equal numbers of seed, and more reproductive biomass than where grazers are absent. These results, together with our literature review, suggest that the timing and organizational scale (individual versus community) of the plant trait measured may differentially influence interpretation of how herbivory influences seed production. Thus, grazing may reduce individual plant fitness, but need not reduce the reproductive capacity of plant communities. However, to answer this, one must assess whether or not grazing affects seed viability in addition to numerical production as was done in our study. There is evidence that defoliation history does not influence seed viability (Orodho et al. 1998), but whether seeds produced by grazed and ungrazed Yellowstone grasses exhibit similar viability is not known. We suggest that early spring defoliation in Yellowstone National Park's northern winter range has played a role in the persistence of grazed plant communities by maintaining community level seed production. Future studies that emphasize the individual versus per unit area effects of grazing on reproductive output may aid in understanding community organization and the sustainability of grazed ecosystems.

\section{Literature Cited}

Agren, J. 1989. Seed size and number in Rubus chamaemorus: between-habitat variation, and effects of defoliation and supplemental pollination. J. Ecol. 77:1080-1092.

Ahlgren, H. L. 1938. Effect of fertilization, cutting treatments, and irrigation on the yield of forage and chemical composition of the rhizomes of Kentucky bluegrass (Poa pratensis). Amer. Soc. Agron. J. 30:683-691.

Aldrich, D. T. A. 1959. The effect of grazing management on the responses of winterwheat to defoliation. Empire J. Exp. Agr. 27:10-16.

Andrade, R. P. and D. Thomas. 1981. Pesquisas em avaliaacao de pastagens e producao de sementes de forrageiras no centro de pesquisa agropecuaria dos cerrados, p. 82 . In: R. B. Madeiros et al. (eds.) Producao e technologia de sementes de forrageiras tropicais e subtropicais, Promocao COTRIJUI/UFRGS/FAO, Porto Alegre e IJUI/RS, Brasil.

Archer, S. and L. L. Tieszen. 1983. Effects of simulated grazing on foliage and root production and biomass allocation in an arctic tundra sedge (Eriophorum vaginatum). Oecologia 58:92-108.

Augustine, D. J. and D. A. Frank. 2001. Effects of migratory grazers on spatial heterogeneity of soil nitrogen properties in a grassland ecosystem. Ecol. 82:3149-3162.

Augustine, D. J. and L. E. Frelich. 1998. The effects of white-tailed deer on populations of an understory forb in fragmented deciduous forests. Conserv. Biol. 12:995-1004.

Bastrenta, B. and E. Belhassen. 1992. The effects of simulated grazing on survival and reproduction of Anthyllis vulneraria. Acta Ecol. 13:787-796.

Bean, E. W., A. J. H. Carr, D. J. Griffiths, J. Lewis, R. H. D. Pegler, H. M. Roberts, and J. L. Stoddart. 1979. Principles of herbage seed production. Tech. Bull. 1. Welsh Plant Breeding Station, Aberystwyth.

Begum, A. and W. G. Eden. 1965. Influence of defoliation on yield and quality of soybeans. J. Econ. Ent. 58:591-592.

Belsky, A. J. 1986a. Does herbivory benefit plants? A review of the evidence. Amer. Natur. 127:870-892.

Belsky, A. J. 1986b. Revegetation of artificial disturbances in grassland of Serengeti National Park, Tanzania. I. Colonization of grazed and ungrazed plots. J. Ecol. 74:419-437.

Belsky, A. J. 1986c. Population and community processes in a mosaic grassland in the Serengeti, Tanzania. J. Ecol. 74:841-856.

Bentley, S., J. B. Whittaker, and A. J. C. Malloch. 1980. Field experiments on the effects of grazing by a chrysomelid bettle (Gastrophysa viridula) on seed production and quality in Rumex obtusifolia and Rumex crispus. J. Ecol. 68:671-674.

Blaisdell, J. P. and J. F. Pechanec. 1949. Effects of herbage removal at various dates on vigor of bluebunch wheatgrass and arrowleaf balsamroot. Ecol. 30:298-305.
Boscher, J. 1979. Modified reproduction strategy in a leek Allium porrum in response to a phytophagus insect, Acrolepiopsis assectella. Oikos 33:451-456.

Brathen, K. A. and A. M. Odasz-Albrigtsen. 2000. Tolerance of the arctic graminoid Luzula arcuta ssp. Confusa to simulated grazing in two nitrogen environments. Can. J. Bot. 78:1108-1113.

Brejda, J. J., J. R. Brown, G. W. Wyman, and W. K. Schumacher. 1994. Management of switchgrass for forage and seed production. J. Range Manage. 47:22-27.

Brown, K. R. 1980. Seed production in New Zealand Rye grass: I. Effect of grazing.New Zeal. J. Exp. Agr. 8:27-32.

Brown, R. F. 1985. The effect of severe defoliation on the subsequent growth and development of five rangeland pasture grasses of south - western Queensland. Aust. J. Ecol. 10:335-343.

Butler, J. L. and D. D. Briske. 1988. Population structures and tiller demography of the bunchgrass Schizachyrium scoparium in response to herbivory. Oikos 51:306-312.

Caldwell, M. M., J. H. Richards, D. A. Johnson, R. S. Nowak, and R. S. Dzurec. 1981. Coping with herbivory: photosynthetic capacity and resource allocation in two semiarid Agropyron bunchgrasses. Oecologia 50:14-24

Collins, W. J., I. Rhodes, R. C. Rossiter, and M. J. Palmer. 1983. The effect of defoliation on seed yield of two strains of subterranean clover grown in monocultures and in binary mixtures. Aust. J. Agr. Res. 34:671-679.

Conlan, D. J., B. S. Dear, and N. E. Coombes. 1994. Effects of grazing intensity and number of grazings on herbage production and seed yields of Trifolium subterraneum, Medicago murex, and Ornithopus compessus. Aust. J. Exp. Agr. 34:181-188.

Cottam, G. and J. T. Curtis. 1956. The use of distance measures in phytosociological sampling. Ecol. 37:451-460.

Coughenour, M. B. 1991. Biomass and nitrogen responses to grazing of upland steppe on Yellowstone's northern winter range. J. Appl. Ecol. 28:71-82.

Crawley, M. J. 1983. Herbivory: The Dynamic of animal - plant interactions. Univ. Calif. Press, Berkeley, Calif.

Crawley, M. J. 1985. Reduction of oak fecundity by low - density herbivore populations. Nature 314:163-164.

Cutler, G. H., D. Pavez, and R. R. Mulvey. 1949. The effects of clipping to simulate pasturing winter wheat on the growth, yield, and quality of the crop. Agron. J. 41:169-173.

Damhoureyeh, S. A. and D. C. Hartnett. 1997. Effects of bison and cattle on growth, reproduction and abundances of five tallgrass prairie forbs. Amer. J. Bot. 84:1719-1728.

Day, A. D., R. K. Thompson, and W. F. McCaughey. 1968. Effects of clipping on the performance of spring barley (Hordeum vulgare L. emend Lam) seeded in October. Agron. J. 60:11-12.

Detling, J. K. and E. L. Painter. 1983. Defoliation responses of western wheatgrass populations with diverse histories of prairie dog grazing. Oecologia 57:65-71. 
Diz, D. A., S. C. Schank, and D. S. Wofford 1995. Defoliation effects and seed yield components in pearl millet $\mathrm{x}$ elephantgrass hybrids. Agron. J. 87:56-62.

Dominguez, C. A. and R. Dirzo. 1994. Effects of defoliation on Erythroxylum havanense, a tropical proleptic species. Ecol. 75:18961902.

Dyer, M. I. 1975. The effects of red-winged blackbirds (Agelaius phoeniceus L.) on biomass production of corn grains (Zea mays L.). J. Appl. Ecol. 12:719-726.

Edwards, J. 1985. Effects of herbivory by moose on flower and fruit production of Aralia nudicaulis. J. Ecol. 73:861-868.

El-Shatnawi, M. K. J., H. Z. Ghosheh, H. K. Shannag, and K. I. Ereifej. 1999. Defoliation time and intensity of wall barley in the Mediterranean rangeland. J. Range Manage. 52:258-262.

Epstein, H. E., W. K. Lauenroth, I. C. Burke, and D. P. Coffin. 1997. Productivity patterns of $\mathrm{C}_{3}$ and $\mathrm{C}_{4}$ functional types in the U.S. Great Plains. Ecol. 78:722-731.

Evans, D. W. 1975. 'Cougar' Kentucky bluegrass seed production as affected by clipping to simulate grazing. Crop Sci. 15:601-602.

Finnell, H. H. 1929. Relations of grazing to wheat smut and tillering. J. Amer. Soc. Agron. 21:367-374

Fowler, N. L. and M. D. Rausher. 1985. Joint effects of competitors and herbivores on growth and reproduction in Aristolochia reticulata. Ecol. 66:1580-1587.

Frank, D. A. and P. M. Groffman. 1998. Ungulate vs. landscape control of soil $\mathrm{C}$ and $\mathrm{N}$ processes in grasslands of Yellowstone National Park. Ecol. 79:2229-2241.

Frank, D. A. and S. J. McNaughton. 1990. Aboveground biomass estimation with the canopy intercept method: a plant growth form caveat. Oikos 57:57-60.

Frank, D. A., S. J. McNaughton, and B. F. Tracy. 1998. The ecology of the earth's grazing ecosystems: comparing the Serengeti and Yellowstone. Biosci. 48:513-521.

Gardner, F. P. and S. C. Wiggans. 1960. Effect of clipping and nitrogen fertilization on forage and grain yields of spring oats. Agron. J. 52:566-568.

George, J. R., G. S. Reigh, R. E. Mullen, and J. J. Hunczak. 1990. Switchgrass herbage and seed yield and quality with partial spring defoliation. Crop Sci. 30:845-849.

Goergen, E. and C. C. Daehler. 2001. Reproductive ecology of a native Hawaiian grass (Heteropogon contortus; poaceae) versus its invasive alien competitor (Pennisetum setaceum; poaceae). Int. J. Plant Sci. 162:317-326.

Hanson, W. R., and L. A. Stoddart. 1941. Effects of grazing upon bunch wheat grass. J. Amer. Soc. Agron. 32:278-289.

Harrison, T. and J. T. Romo. 1994. Regrowth of smooth bromegrass (Bromus inermis Leyss.) following defoliation. Can. J. Plant Sci. 74:531-537.
Hart, R. H. and E. F. Balla. 1982. Forage production and removal from western and crested wheatgrasses under grazing. J. Range Manage. 35:362-366.

Hartnett, D. C. 1989. Density- and growth stage-dependent responses of defoliation in two rhizomatous grasses. Oecologia 80:414-420.

Hebblethwaite, P. D. and T. G. A. Clemence. 1983. Effect of autumn and spring defoliation and defoliation method on seed yield of Lolium perenne, p. 257-260. In J.A. Smith and V.W. Hays (eds.) Proc. $14^{\text {th }}$ Int. Grassl. Congr., Lexington, Ky.

Heckathorn, S. A. and E. H. Delucia. 1996. Retranslocation of shoot nitrogen to rhizomes and roots in prairie grasses may limit loss of $\mathrm{N}$ to grazing and fire during drought. Functional Ecol. 10:396-400.

Heckathorn, S. A., S. J. McNaughton, and J. S. Coleman. 1999. $C_{4}$ plants and herbivory, p. 285-312. In: R. F. Sage and R. K. Monson (eds.) $\mathrm{C}_{4}$ Plant biology. Academic Press, San Diego, Calif.

Hendrix, S. D. 1979. Compensatory reproduction in a biennial herb following insect defloration. Oecologia 42:107-118.

Herron, G. R. 1976. Influence of grazing and nitrogen fertilization on winter growth, seed and straw production of Lolium multiflorum Lam. M.S. Thesis, Oregon State Univ., Corvallis, Ore.

Hickey, W. C. 1961. Growth form of crested wheatgrass as affected by site and grazing. Ecol.. 42:173-176.

Houston, D. B. 1982. The northern yellowstone elk. Macmillan publishing, New York, N.Y.

Hubbard, V. C. and H. J. Harper. 1949. Effects of clipping small grains on composition and yield of forage and grain. Agron. J. 41:85-92.

Inouye, D. W. 1982. The consequences of herbivory: a mixed blessing for Jurinea mollis (Asteraceae). Oikos 39:269-272.

Jameson, D. A. 1963. Responses of individual plants to harvesting. Biol. Rev. 29:532-594.

Jaramillo, V. J. and J. K. Detling. 1988. Grazing history, defoliation, and competition: effects on shortgrass production and nitrogen accumulation. Ecol. 69:1599-1608.

Jewiss, O. R. 1972. Tillering in grasses: its significance and control. J. Brit. Grassl. Soc. 27:65-82.

Jones, R. M. 1968. Seed production of species in the Highveld secondary succession. J. Ecol. 56:661-666.

Jones, T. A. and D. C. Nielson. 1993. Springclipping response in snake river and thickspike wheatgrass. Agron. J. 85:94-97.

Keefer, W. R. 1987. The geological story of Yellowstone Park. Yellowstone Library and Museum Assoc., Mammoth, Wyo.

Kemp, W. B. 1937. Natural selection within plant species exemplified in a permanent pasture. J. Heredity 28:329-333.

Keya, G. A. 1997. Effects of defoliation on yield and reproduction of the dwarf shrub Indigofera spinosa. Acta Oecologia 18:449-463.
Kinsman, S. and W. J. Platt. 1984. The impact of a herbivore upon Mirabilis hirsuta, a fugitive prairie plant. Oecologia 65:2-6.

Kinucan, R. J. and F. E. Smeins. 1992. Soil seed bank of a semiarid Texas grassland under three long-term (36-years) grazing regimes. Amer. Mid. Nat. 128:11-21.

Kittock, D. L. and J. H. Williams. 1967. Effect of leaf removal at four stages of growth on yield of castorbeans. Agron. J. 59:489-490.

Knight, W. E. and E. A. Hollowell. 1962. Response of crimson clover to different defoliation intensities. Crop Sci. 2:124-127.

Koptur, S., C. L. Smith, and J. H. Lawton. 1996. Effects of artificial defoliation on reproductive allocation in the common vetch, Vicia sativa (Fabaceae: Papilionoideae). Amer. J. Bot. 83:886-889.

Kroth, E., R. Mattas, L. Meinke, and A. Matches. 1977. Maximizing production potential of tall fescue. Agron. J. 69:319-322.

Laude, H. M., A. Kadish, and R. M. Love. 1957. Differential effects of herbage removal on range species. J. Range Manage. $10: 116-120$.

Lee, T. D. and F. A. Bazzaz. 1980. Effects of defoliation and competition on growth and reproduction in the annual plant Abutilion theophrasti. J. Ecol. 68:813-821.

Lehtila, K. and K. Syrjanen. 1995. Compensatory responses of two Melampyrum species after damage. Functional Ecol. 9:511-517.

Lennartsson, T. P. Nilsson, and J. Tuomi. 1998. Induction of overcompensation in the field gentian, Gentianella campestris. Ecol.. 79:1061-1072.

Lokker, C. and P. B. Cavers. 1995. The effects of physical damage on seed production in flowering plants of Saponaria officinalis. Can. J. Bot. 73:235-243.

Louda, S. M. 1984. Herbivore effect on stature, fruiting, and leaf dynamics of a native crucifer. Ecol. 65:1379-1386.

Lubbers, A. E. and M. J. Lechowicz. 1989. Effects of leaf removal on reproduction vs. belowground storage in Trillium grandiflorum. Ecol. 70:85-96.

Marquis, R. J. 1984. Leaf herbivores decrease fitness of a tropical plant. Sci. 226:537-539.

Maschinski, J. and T. G. Whitham. 1989. The continuum of plant responses to herbivory: the influence of plant association, nutrient availability, and timing. Amer. Natur. 134:1-19.

McLean, A. and S. Wikeem. 1985. Influence of season and intensity of defoliation on bluebunch wheatgrass survival and vigor in southern British Columbia. J. Range Manage. 38:21-26.

McNaughton, S. J. 1979. Grassland-herbivore dynamics, p. 46-81. In: A.R.E. Sinclair and M. Norton-Griffiths (eds.) Serengeti: Dynamics of an ecosystem. Univ. of Chicago Press, Chicago, Ill

McNaughton, S. J., L. L. Wallace, and M. B. Coughenour. 1983. Plant adaptation in an ecosystem context: effects of defoliation, 
nitrogen, and water on the growth of an African $\mathrm{C}_{4}$ sedge. Ecol. 64:307-318.

Mendoza, A., D. Pinero, and J. Sarukhan. 1987. Effects of experimental defoliation on the growth, reproduction and survival of Astrocaryum mexicanum. J. Ecol. 75:545-554.

Meyer, G. A. and R. B. Root. 1993. Effects of herbivorous insects and soil fertility on reproduction of goldenrod. Ecol. 74:1117-1128.

Michaud, J. P. 1991. Biomass allocation in fireweed Epilobium angustifolium L. (Onagraceae) in response to simulated defoliation. Bot. Gaz. 152:208-213.

Miller, G. L., R. E. Joost, and S. A. Harrison. 1993. Forage and grain yields of wheat and triticale as affected by forage management practices. Crop Sci. 33:1070-1075.

Milton, S. J. 1995. Effects of rain, sheep and tephritid flies on seed production of two arid Karoo shrubs in South Africa. J. Appl. Ecol. 32:137-144.

Morris, H. D. and F. P. Gardner. 1958. The effects of nitrogen fertilization and duration of clipping period on forage and grain yields of oats, wheat, and rye. Agron. J. 50:454-457.

Mueggler, W. F. 1967. Response of mountain grassland vegetation to clipping in southwestern Montana. Ecol. 48:942-949.

Mueggler, W. F. 1972. Influence of competition on the response of bluebunch wheatgrass to clipping. J. Range Manage. 25:88-92.

Mueggler, W. F. 1975. Rate and pattern of vigor recovery in Idaho fescue and bluebunch wheatgrass. J. Range Manage. 28:198-204.

Muir, J. P. and W. D. Pitman. 1991. Response of Desmanthus virgatus, Desmodium heterocarpon, and Galactia elliottii to defoliation. Tropical Grassl. 25:291-296.

Mulder, C. P. H. and R. W. Ruess. 1998. Relationships between size, biomass allocation, reproduction, and survival in Triglochin palustris: implications for the effects of goose herbivory. Can. J. Bot. 76:2164-2176.

Myers, J. H. 1981. Interactions between western tent caterpillars and wild rose: a test of some general plant herbivore hypotheses. J. Anim. Ecol. 50:11-25.

Neiland, B. M. and J. T. Curtis. 1956. Differential responses to clipping of six prairie grasses in Wisconsin. Ecol. 37:355-365.

NOAA [National Oceanic and Atmospheric Association]. 2001. Climatological data for Wyoming. United States Department of Commerce, Washington D.C., USA.

Noy-Meir, I. and D. D. Briske. 2002. Response of wild wheat populations to grazing in Mediterranean grasslands: the relative influence of defoliation, competition, mulch and genotype. J. App. Ecol. 39:259-278.

O'Connor, T. G. and G. A. Pickett. 1992. The influence of grazing on seed production and seed banks of some African savanna grasslands. J. Appl. Ecol. 29:247-260.

Olson, B. E., R. T Wallander, and J. R. Lacey. 1997. Effects of sheep grazing on a spotted knapweed-infested Idaho fescue community. J. Range Manage. 50:386-390.

Orodho, A. B., R. L. Cuany, and M. J. Trlica. 1998. Previous grazing or clipping affects seed of Indian ricegrass. J. Range Manage. 51:37-41.

Paige, K. N. and T. G. Whitham. 1987. Overcompensation in response to mammalian herbivory: the advantage of being eaten. Amer. Natur. 129:407-416.

Painter, E. L., J. K. Detling, and D. A Steingraeber. 1989. Grazing history, defoliation, and frequency-dependent competition: effects on two North American grasses. Amer. J. Bot. 76:1368-1379.

Painter, E. L., J. K. Detling, and D. A Steingraeber. 1993. Plant morphology and grazing history. Vegetatio 106:37-62.

Pechan, P. A. and D. G. Morgan. 1985. Defoliation and its effect on pod and seed development in oil seed rape (Brassica napus L.). J. Exp. Bot. 36:458-468.

Pemadasa, M. A. and L. Amarasinghe. 1982. The ecology of a montane grassland in Sri Lanka. J. Ecol. 70:731-744.

Pfeiffer, K. E. and D. C. Hartnett. 1995. Bison selectivity and grazing response of little bluestem in tallgrass prairie. J. Range Manage. 48:26-31.

Pickle, C. S. and C. E. Caviness. 1984. Yield reduction from defoliation and plant cutoff of determinate and semideterminate soybean. Agron. J. 76:474-476.

Pumphrey, F. V. 1970. Semidwarf winter wheat response to early spring clipping and grazing. Agron. J. 62:641-643.

Rausher, M. D. and P. Feeny. 1980. Herbivory, plant density, and plant reproductive success: the effect of Battus philenor on Aristolochia reticulata. Ecol. 61:905-917.

Roberts, H. M. 1958. The effects of defoliation on the seed-producing capacity of bred strains of grasses. I. Timothy and perennial ryegrass. J. Brit. Grassl. Soc. 13:255-261.

Roberts, H. M. 1965. The effects of defoliation on the seed-producing capacity of bred strains of grasses. III. Varieties of perennial ryegrass, cocksfoot, meadow fescue and timothy. J. Brit. Grassl. Soc. 20:283-289.

Rockwood, L. L. 1973. The effect of defoliation on seed production of six Costa Rican tree species. Ecol. 54:1363-1369.

Ruess, R. W., S. J. McNaughton, and M. B. Coughenour. 1983. The effects of clipping, nitrogen source and nitrogen concentration on the growth responses and nitrogen uptake of an East African sedge. Oecologia 59:253-261.

Sacchi, C. F., P. W. Price, T. P. Craig, and J. K. Itami. 1988. Impact of shoot galler attack on sexual reproduction in the Arroyo willow. Ecol. 69:20121-2030.

Scott, A. W. and R. D. B. Whaley. 1984. The influence of intensive sheep grazing on genotypic differentiation in Danthonia linkii, $D$. richardsonii, and D. racemosa on the New England tablelands. Aust. J. Ecol. 9:419-429.

Sharrow, S. H. and I. Motazedian. 1987. Spring grazing effects on components of winter wheat yield. Agron. J. 79:502-504.
Silva, J. F. and J. Raventos. 1999. Effects of dry season shoot removal on the growth of three savanna grasses with different phenologies. Biotropica 31:430-438.

Simmons, S. R., R. K. Crookston, and J. E. Kurle. 1982. Growth of spring wheat kernels influenced by reduced kernel number per spike and defoliation. Crop Sci. 22:983-988.

Sims, P. L., L. J. Ayuko, and D. N. Hyder. 1971. Developmental morphology of switchgrass and sideoats grama. J. Range Manage. 24:357-360.

Singer, F. J. 1995. Effects of grazing by ungulates on upland bunchgrass communities of the northern winter range of Yellowstone National Park. Northwest Sci. 69:191-203.

Singer, F. J. and J. A. Mack. 1993. Potential ungulate prey for gray wolves, p. 75-117. In R.S. Cook (ed.) Ecological issues on reintroducing wolves into Yellowstone National Park. U.S. Dept. Interior Sci. Monogr. NPS/NR Yell/NRSM - 93/22, Washington, D.C.

Smith, S. E. 1998. Variation in response to defoliation between populations of Bouteloua curtipendula var. caespitosa (Poaceae) with different livestock grazing histories. Amer. J. Bot. 85:1266-1272.

Smith, S. E., R. Mosher, and D. Fendenheim. 2000. Seed production in sideoats grama populations with different grazing histories. J. Range Manage. 53:550-555.

Smyth, M. J., A. W. Sheppard, and A. Swirepik. 1997. The effect of grazing on seed production in Echium plantagineum. Weed Res. 37:63-70.

Sneva, F. A. 1977. Correlations of precipitation and temperature with spring, regrowth, and mature crested wheatgrass yields. J. Range Manage. 30:270-275.

Sprauge, M. A. 1954. The effect of grazing management of forage and grain productionfrom rye, wheat, and oats. Agron. J. 46:29-33

Stamp, N. E. 1984. Effect of defoliation by checkerspot caterpillars (Euphydryas phaeton) and sawfly larvae (Macrophya nigra and Tenthredo grandis) on their host plants (Chelone spp.). Oecologia 63:275-280.

Stapledon, R. G. 1928. Cocksfoot grass (Dactylis glomerata L.): ecotypes in relation to the biotic factor. J. Ecol. 116:71-104.

Statistica. 1998. Kernel release 5.1, StatSoft Inc., Tulsa, Okla.

Steiner, J. J. and D. F. Grabe. 1986. Sheep grazing effects on subterranean clover development and seed production in western Oregon. Crop Sci. 26:367-372.

Stephenson, A. G. 1980. Fruit set, herbivory, fruit reduction, and the fruiting strategy of Catalpa speciosa (Bignoniaceae). Ecol.6:57-64.

Strauss, S. Y. 1991. Direct, indirect, and cumulative effects of three native herbivores on a shared host plant. Ecol. 72:543-558.

Stolgren, T. J., L. D. Schell, and B. Vanden Heuvel. 1999. How grazing and soil quality affect native and exotic plant diversity in rocky mountain grasslands. Ecol. Appl. 9:45-64. 
Tainton, N. M. and P. De V. Booysen. 1965. Growth and development in perennial veld grasses. I. Themeda triandra tillers under various systems of defoliation. S. Afr. J. Agr. Sci. 8:93-110.

Teigen, J. B. and J. J. Vorst. 1975. Soybean response to stand reduction and defoliation. Agron. J. 67:813-815.

Thakur, C. and H. L. Shands. 1954. Spring small grain agronomic response to plant clipping when seeded at two rates and fertilized at two levels of nitrogen. Agron. J. 46:15-19.

Thomas, G. D., C. M. Ignoffo, K. D. Biever, and D. B. Smith. 1974. Influence of defoliation and depodding on yield of soybeans. J. Econ. Entomol. 67:683-685.

Trlica, M. J. and A. B. Orodho. 1989. Effects of protection from grazing on the morphological and chemical characteristics of Indian ricegrass, Oryzopsis hymenoides. Oikos 56:299-308.

Van Auken, O. W. 1994. Changes in competition between a $\mathrm{C}_{4}$ grass and a woody legume with differential herbivory. Southwest Nat. 39:114-121.
Vinton, M. A. and D. C. Hartnett. 1992. Effects of bison grazing on Andropogon gerardii and Panicum virgatum in burned and unburned tallgrass prairie. Oecologia 90:374-382.

Wallace, L. L. 1987. Effects of clipping and soil compaction on growth, morphology and mycorrhizal colonization of Schizachyrium scoparium, a $\mathrm{C}_{4}$ bunchgrass. Oecologia $72: 423-428$.

Washko, J. B. 1947. The effects of grazing winter small grains. J. Amer. Soc. Agron. 39:659-666.

Watson, C. E. and V. H. Watson. 1982. Nitrogen and date of defoliation effects on seed yield and seed quality of tall fescue. Agron. J. 74:891-893.

Whitham, T. G., J. Maschinski, K. C. Larson, and K. N. Paige. 1991. Plant responses to herbivory: the continuum from negative to positive and underlying physiological mechanisms, p. 227-257. In: P.W. Price T.M. Lewinsohn, G.W. Fernandes, and W.W. Benson (eds.) Plant - animal interactions: Evolutionary ecology in tropical and temperature regions. John Wiley and Sons, Inc., New York, N.Y.
Willms, D. and D. A. Quinton. 1995. Grazing effects on germinable seeds on the fescue prairie. J. Range Manage. 48:423-430.

Winter, S. R. and E. K. Thompson. 1987. Grazing duration effects on wheat growth and grain yield. Agron. J. 79:110-114.

Woronecki, P. P., R. A. Stehn, and R. A. Dolbeer. 1980. Compensatory response of maturing corn kernels following simulated damage by birds. J. Appl. Ecol. 17:737-746.

Young, W. C., III, D. O. Chilcote, and H. W. Youngberg. 1996. Annual ryegrass seed yield response to grazing during early stem elongation. Agron. J. 88:211-215.

Appendix 1. Defoliation impacts on the production of reproductive biomass, from 118 published sources, reported as positive (+), negative (-), or no effect (0). Results are separated by the timing of defoliation (early, intermediate, or late) when possible. Study species are grouped hierarchically by study scale (whole plot or individual plant), vegetation type (graminods, non-graminoids, or seed bank study), method of defoliation (cutting, grazing, transplant of previously grazed species, or removal of flowers or seeds), and identity of herbivore (ungulate or insect). References and notes are identified with superscripts. Study types are field (F), laboratory (L), and garden (G), which includes planted agricultural fields.

\begin{tabular}{|c|c|c|c|c|c|c|}
\hline \multirow{3}{*}{ Species } & \multirow{3}{*}{$\begin{array}{l}\text { Plant } \\
\text { Functional } \\
\text { Type }\end{array}$} & \multirow{3}{*}{$\begin{array}{l}\text { Study } \\
\text { Type }\end{array}$} & \multirow{2}{*}{\multicolumn{3}{|c|}{ Timing }} & \multirow[b]{3}{*}{ Citation } \\
\hline & & & & & & \\
\hline & & & Early & Intermediate & Late & \\
\hline \multicolumn{7}{|l|}{ Whole-plot studies } \\
\hline \multicolumn{7}{|l|}{ Graminiods } \\
\hline \multicolumn{7}{|l|}{ Grazing } \\
\hline $\begin{array}{l}\text { Agropyron spicatum } \\
\text { (Prush) Scribn. \& Smith }\end{array}$ & $\mathrm{C}_{3}$ grass & $\mathrm{F}$ & & - & & Hanson and Stoddart 1941 \\
\hline Andropogon greenwayi Napp. & $\mathrm{C}_{4}$ grass & $\mathrm{F}$ & & - & & Belsky 1986c \\
\hline Avena $\mathrm{sp}^{1}$ & $\mathrm{C}_{3}$ grass & $\mathrm{G}$ & 0 & & $0(+)$ & Sprauge 1954 \\
\hline Avena sp. $^{2}$ & $\mathrm{C}_{3}$ grass & G & & - & & Washko 1947 \\
\hline Festuca idahoensis Elmer & $\mathrm{C}_{3}$ grass & $\mathrm{F}$ & & 0 & & Olson et al. 1997 \\
\hline Hordeum sp. $^{2}$ & $\mathrm{C}_{3}$ grass & $\mathrm{G}$ & & - & & Washko 1947 \\
\hline Lolium $\mathrm{sp.}^{3}$ & $\mathrm{C}_{3}$ grass & $\mathrm{G}$ & & $-(+)$ & & Brown 1980 \\
\hline Lolium multiflorum Lam $^{4}$ & $\mathrm{C}_{3}$ grass & $\mathrm{G}$ & $+(0)$ & $+(0)$ & $+(0)$ & Young et al. 1996 \\
\hline Lolium multiflorum Lam. & $\mathrm{C}_{3}$ grass & $\mathrm{G}$ & - & & & Herron 1976 \\
\hline Lolium perenne $\mathrm{L}$. & $\mathrm{C}_{3}$ grass & $\mathrm{G}$ & 0 & 0 & & Hebblethwaite and Clemence 1983 \\
\hline Lolium perenne L. $^{5}$ & $\mathrm{C}_{3}$ grass & $\mathrm{G}$ & 0 & & $0(-)$ & Roberts 1958 \\
\hline Phleum sp. ${ }^{5}$ & $\mathrm{C}_{3}$ grass & $\mathrm{G}$ & 0 & & $-(0)$ & Roberts 1958 \\
\hline Secale sp. ${ }^{1}$ & $\mathrm{C}_{3}$ grass & G & + & & $-(-)$ & Sprauge 1954 \\
\hline Secale sp. $^{2}$ & $\mathrm{C}_{3}$ grass & G & & - & & Washko 1947 \\
\hline Triticum aestivum $\mathrm{L}^{6}{ }^{6}$ & $\mathrm{C}_{3}$ grass & G & - & - & - & Pumphrey 1970 \\
\hline Triticum aestivum $\mathrm{L}$. & $\mathrm{C}_{3}$ grass & G & + & & & Sharrow and Motazedian 1987 \\
\hline Triticum aestivum $\mathrm{L} .{ }^{1}$ & $\mathrm{C}_{3}$ grass & G & + & & $-(-)$ & Sprauge 1954 \\
\hline Triticum aestivum $\mathrm{L}^{2}{ }^{2}$ & $\mathrm{C}_{3}$ grass & G & - & & & Washko 1947 \\
\hline Triticum aestivum L. $^{7}$ & $\mathrm{C}_{3}$ grass & $\mathrm{G}$ & 0 & - & - & Winter and Thompson 1987 \\
\hline Triticum dicoccoides & $\mathrm{C}_{3}$ grass & G & & $0(+)$ & $-(-)$ & Noy-Meir and Briske 2002 \\
\hline Unspecified grasses & $\mathrm{C} 4$ grass & $\mathrm{F}$ & & - & & McNaughton 1979 \\
\hline \multicolumn{7}{|l|}{ Cutting } \\
\hline $\begin{array}{l}\text { Agropyron spicatum } \\
\text { (Prush) Scribn. \& Smith }\end{array}$ & $\mathrm{C}_{3}$ grass & $\mathrm{F}$ & - & - & - & Blaisdell and Pechanec 1949 \\
\hline
\end{tabular}




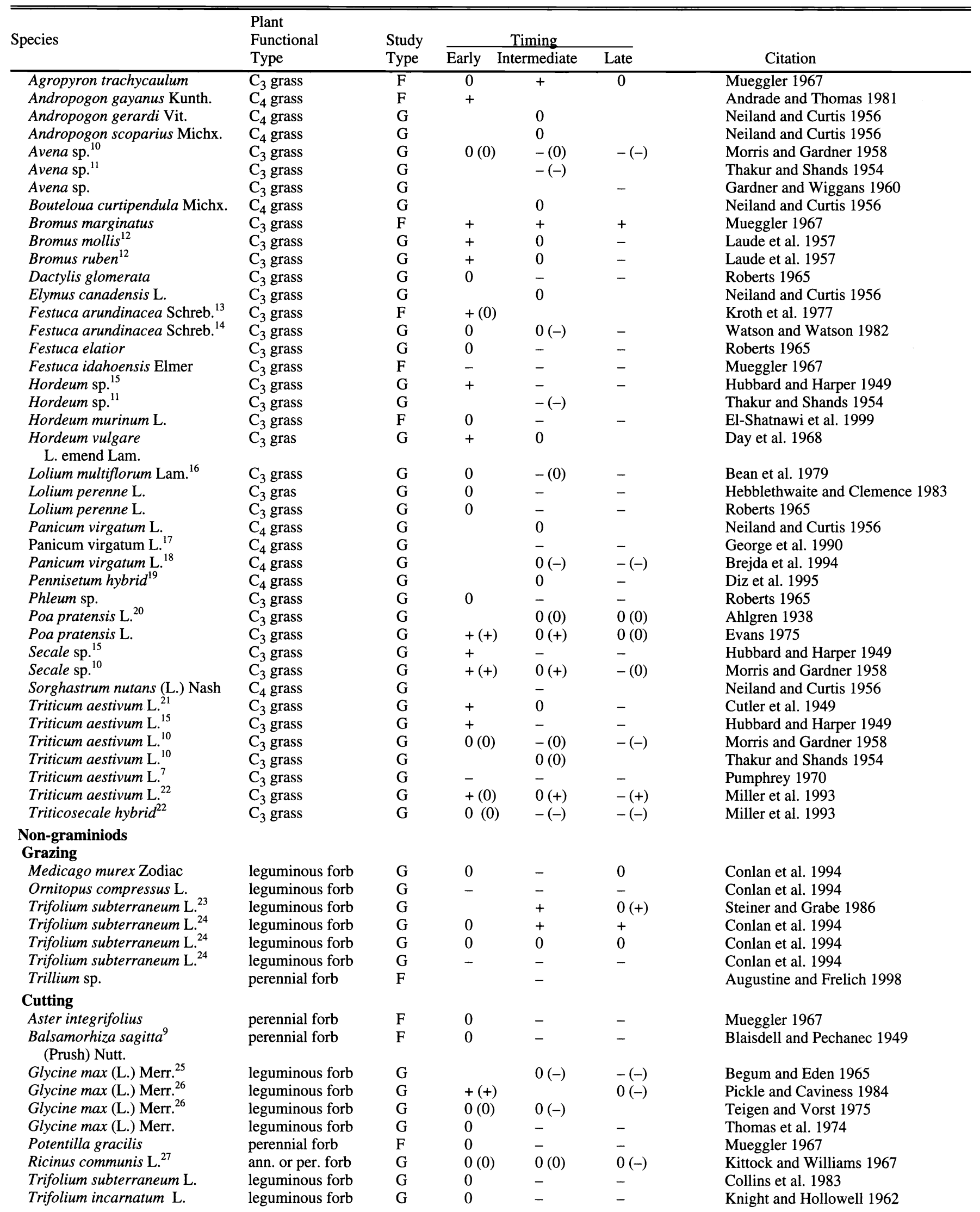




\begin{tabular}{|c|c|c|c|c|c|c|}
\hline \multirow[t]{2}{*}{ Species } & \multirow{2}{*}{$\begin{array}{l}\text { Plant } \\
\text { Functional } \\
\text { Type }\end{array}$} & \multirow{2}{*}{$\begin{array}{l}\text { Study } \\
\text { Type }\end{array}$} & \multicolumn{3}{|c|}{ Timing } & \multirow[b]{2}{*}{ Citation } \\
\hline & & & Early I & Intermediate & Late & \\
\hline \multicolumn{7}{|l|}{ Seed banks } \\
\hline \multicolumn{7}{|l|}{ Grazing } \\
\hline Grasses and forbs ${ }^{28}$ & & $\mathrm{~F}$ & & 0 & & Kinucan and Smeins 1992 \\
\hline Grasses and forbs ${ }^{28}$ & & $\mathrm{~F}$ & & + & & Willms and Quinton 1995 \\
\hline \multicolumn{7}{|l|}{ Individual Plant Studies } \\
\hline \multirow{2}{*}{\multicolumn{7}{|c|}{$\begin{array}{l}\text { Graminiods } \\
\text { Grazing }\end{array}$}} \\
\hline & & & & & & \\
\hline Andropogon gerardii Vit. & $\mathrm{C}_{4}$ grass & $\mathrm{F}$ & & 0 & & Vinton and Hartnett 1992 \\
\hline Festuca idahoensis Elmer & $\mathrm{C}_{3}$ grass & $\mathrm{F}$ & & 0 & & Olson et al. 1997 \\
\hline Lolium multiflorum Lam. & $\mathrm{C}_{3}$ grass & $\mathrm{G}$ & & + & & Herron 1976 \\
\hline $\begin{array}{l}\text { Oryzopsis hymenoides } \\
\text { (Roem. \& Schult.) Ricker }\end{array}$ & $\mathrm{C}_{3}$ grass & $\mathrm{F}$ & & 0 & & Trlica and Orodho 1989 \\
\hline $\begin{array}{l}\text { Oryzopsis hymenoides } \\
\quad \text { (Roem. \& Schult.) Ricker }\end{array}$ & $\mathrm{C}_{3}$ grass & $\mathrm{F}$ & & 0 & & Orodho et al. 1998 \\
\hline $\begin{array}{l}\text { Panicum virgatum } \mathrm{L} \text {. } \\
\quad \text { Clipping or Defoliation }\end{array}$ & $\mathrm{C}_{4}$ grass & $\mathrm{F}$ & & 0 & & Vinton and Hartnett 1992 \\
\hline $\begin{array}{l}\text { Agropyron desertorum } \\
\text { (Fisch. Ex Link) Schult. }\end{array}$ & $\mathrm{C}_{3}$ grass & $\mathrm{F}$ & & - & & Caldwell et al. 1981 \\
\hline $\begin{array}{l}\text { Agropyron spicatum } \\
\text { (Prush) Scribn. \& Smith }\end{array}$ & $\mathrm{C}_{3}$ grass & $\mathrm{F}$ & & - & & Caldwell et al. 1981 \\
\hline $\begin{array}{l}\text { Agropyron spicatum } \\
\text { (Prush) Scribn. \& Smith }\end{array}$ & $\mathrm{C}_{3}$ grass & $\mathrm{F}$ & - & & - & Mueggler 1972 \\
\hline $\begin{array}{l}\text { Agropyron spicatum } \\
\quad \text { (Prush) Scribn. \& Smith }\end{array}$ & $\mathrm{C}_{3}$ grass & $\mathrm{F}$ & 0 & & - & Mueggler 1975 \\
\hline $\begin{array}{l}\text { Agropyron spicatum } \\
\text { (Prush) Scribn. \& Smith }\end{array}$ & $\mathrm{C}_{3}$ grass & $\mathrm{F}$ & - & - & & McLean and Wikeem 1985 \\
\hline Andropogon gerardii Vit. & $\mathrm{C}_{4}$ grass & $\mathrm{L}$ & & - & & Hartnett 1989 \\
\hline Andropogon gerardii Vit. & $\mathrm{C}_{4}$ grass & $\bar{L}$ & & - & & Heckathorn and Delucia 1996 \\
\hline $\begin{array}{l}\text { Andropogon semiberbis } \\
\text { (Nees) Kunth. }\end{array}$ & $\mathrm{C}_{4}$ gras & $\mathrm{G}$ & & - & & Silva and Raventos 1999 \\
\hline 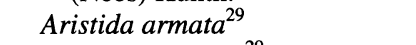 & $\mathrm{C}_{4}$ grass & $\mathrm{L}$ & & & - & Brown 1985 \\
\hline Asrebla lappacea $^{29}$ & $\mathrm{C}_{4}$ grass & $\mathrm{L}$ & & & - & Brown 1985 \\
\hline Bouteloua curtipendula Michx. & $\mathrm{C}_{4}$ grass & $\mathrm{F}$ & 0 & - & - & Sims et al. 1971 \\
\hline Bromis inermis Leyss & $\mathrm{C}_{3}$ grass & $\mathrm{F}$ & 0 & 0 & - & Harrison and Romo 1994 \\
\hline Cenchrus ciliaris $^{29}$ & $\mathrm{C}_{4}$ grass & $\mathrm{L}$ & & & - & Brown 1985 \\
\hline Cynodon dactylon & $\mathrm{C} 4$ grass & $\mathrm{L}$ & 0 & & & Van Auken 1994 \\
\hline Digitaria ammophila ${ }^{29}$ & $\mathrm{C}_{4}$ grass & $\mathrm{L}$ & & & - & Brown 1985 \\
\hline Elymus lanceolatus ${ }^{30}$ & $\mathrm{C}_{3}$ grass & $\mathrm{F}$ & & - & & Jones and Nielson 1993 \\
\hline Elymus lanceolatus $^{30}$ & $\mathrm{C}_{3}$ grass & $\mathrm{F}$ & & $-(0)$ & & Jones and Nielson 1993 \\
\hline Elymus lanceolatus $^{30}$ & $\mathrm{C}_{3}$ grass & $\mathrm{F}$ & & $-(0)$ & & Jones and Nielson 1993 \\
\hline Elymus lanceolatus $^{30}$ & $\mathrm{C}_{3}$ grass & & & 0 & & Jones and Nielson 1993 \\
\hline Elymus lanceolatus ${ }^{30}$ & $\mathrm{C}_{3}$ grass & & & 0 & & Jones and Nielson 1993 \\
\hline Eriophorum vaginatum L. $^{31}$ & $\mathrm{C}_{3}$ sedge & $\mathrm{F}$ & + & 0 & - & Archer and Tieszen 1983 \\
\hline Eulalia trispicata ${ }^{32}$ & $\mathrm{C}_{4}$ grass & $\mathrm{L}$ & $-(-)$ & $-(0)$ & $-(-)$ & Pemadasa and Amarasinghe 1982 \\
\hline Festuca idahoensis Elmer & $\mathrm{C}_{3}$ grass & $\mathrm{F}$ & & 0 & - & Mueggler 1975 \\
\hline $\begin{array}{l}\text { Heteropogon contortus }{ }^{33} \\
\text { (L.) P. Beauv. ex Roem. } \\
\text { \& Schult. }\end{array}$ & $\mathrm{C}_{4}$ grass & $\mathrm{L}$ & & $0(0)$ & & Goergen and Daehler 2001 \\
\hline Kyllinga nervosa Steud. & $\mathrm{C}_{4}$ sedge & $\mathrm{L}$ & & - & & McNaughton et al. 1983 \\
\hline Kyllinga nervosa Stued. & $\mathrm{C}_{4}^{\top}$ sedge & $\mathrm{L}$ & & - & & Ruess et al. 1983 \\
\hline $\begin{array}{l}\text { Luzula arcuat }^{34} \\
\text { Swartz ssp. confusa } \\
\text { (Lindeb.) Blytt }\end{array}$ & $\mathrm{C}_{3}$ sedge & $\mathrm{L}$ & & $0(-)$ & & Brathen et al. 2000 \\
\hline $\begin{array}{l}\text { Panicum virgatum } \\
\text { (L.) var. Caddo }\end{array}$ & $\mathrm{C}_{4}$ grass & $\mathrm{F}$ & 0 & - & - & Sims et al. 1971 \\
\hline Panicum virgatum $\mathrm{L}$. & $\mathrm{C}_{4}$ grass & $\mathrm{L}$ & & - & & Hartnett 1989 \\
\hline Panicum virgatum L. $^{35}$ & $\mathrm{C}_{4}$ grass & $\mathrm{L}$ & & + & & Hartnett 1989 \\
\hline Pennisetum polystachyon ${ }^{32}$ & $\mathrm{C}_{4}$ grass & $\mathrm{L}$ & $-(0)$ & $-(0)$ & $-(0)$ & Pemadasa and Amarasinghe 1982 \\
\hline $\begin{array}{l}\text { Pennisetum setaceum } \\
\text { (Forssk.) Chiov }\end{array}$ & $\mathrm{C}_{4}$ grass & $\mathbf{L}$ & & $0(-)$ & & Goergen and Daehler 2001 \\
\hline $\begin{array}{l}\text { Schizachyrium scoparium } \\
\text { (Michx.) Nash }\end{array}$ & $\mathrm{C}_{4}$ grass & $\mathrm{G}$ & & - & & Wallace 1987 \\
\hline $\begin{array}{l}\text { Schizachyrium scoparium } \\
\text { (Michx.) Nash }\end{array}$ & $\mathrm{C}_{4}$ grass & $\mathrm{L}$ & & - & & Heckathorn and Delucia 1996 \\
\hline Spartina pectina Link & $\mathrm{C}_{4}$ grass & $\mathrm{L}$ & & - & & Heckathorn and Delucia 1996 \\
\hline Themeda triandra & $\mathrm{C}_{4}$ grass & $\mathrm{F}$ & - & & - & Tainton and Booysen 1965 \\
\hline
\end{tabular}




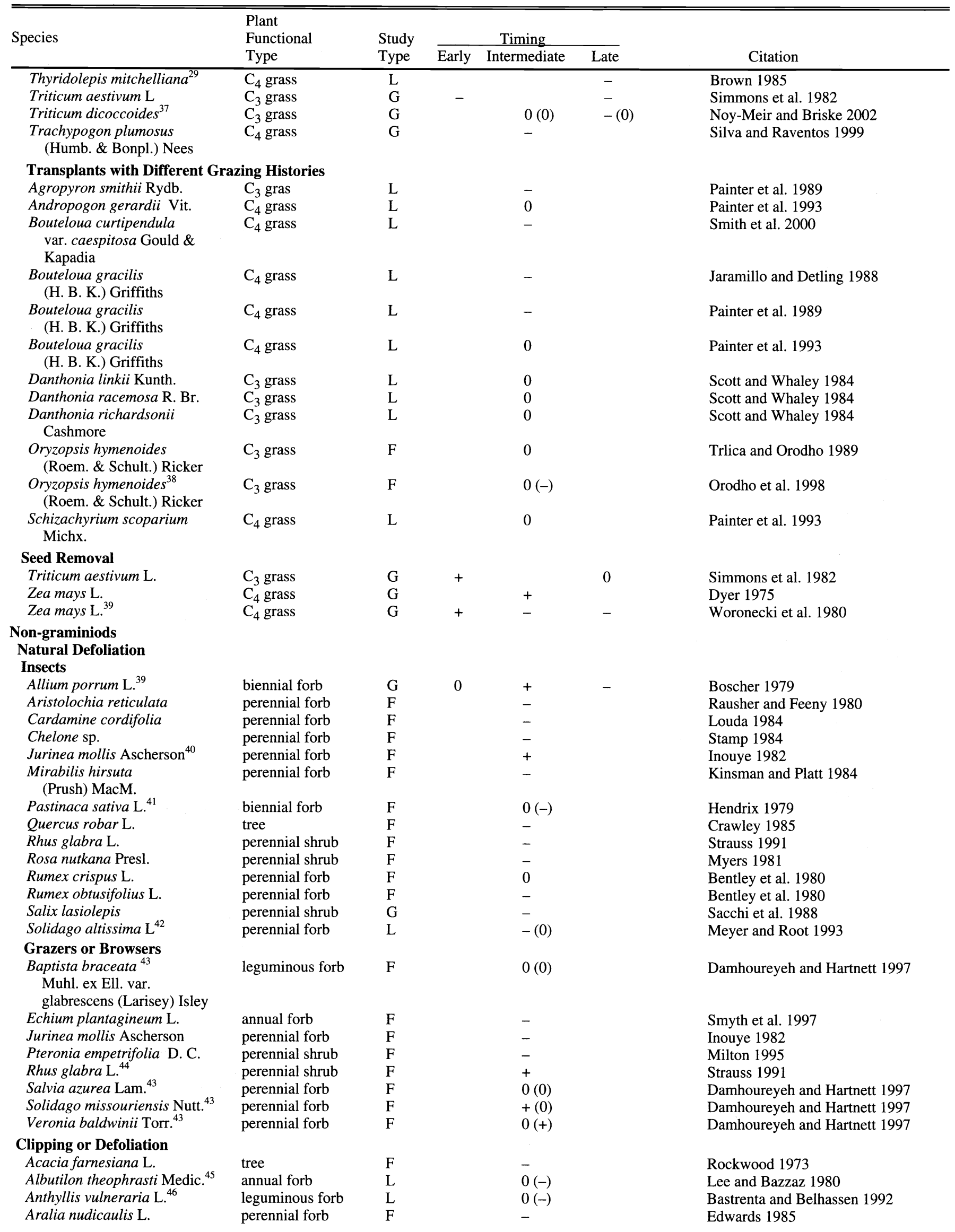




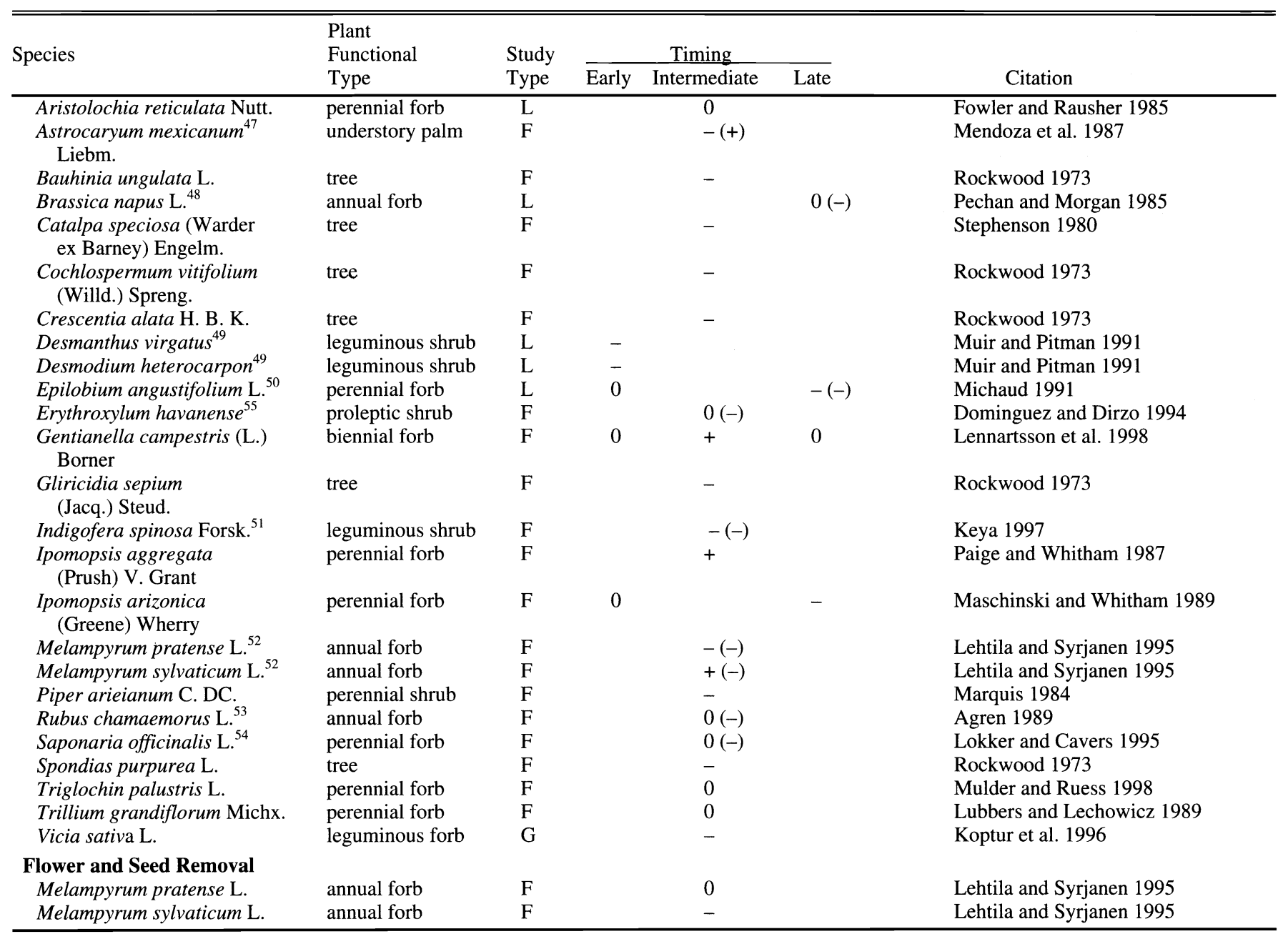

1 - Autumn (early) and spring (late) grazing; spring after fall in parentheses

2 - Spring grazing to March $15+$ fall grazing into November

3 - Results for number of fertile tillers in parentheses

4 - Results are for number of fertile tillers with second year in parentheses; no effect of grazing on seed production in either year

5 - Winter (early) and spring (late) grazing; spring after winter in parentheses

6 - Early treatment similar in timing to intermediate treatment in other studies

7 - Severe grazing in all treatments

8 - Results are for plot level biomass, effect on plot level ratio of reproductive:total biomass shown in parentheses; see reference for taxonomic reference.

9 - Severe clipping; fall clipping had no effect

$10-2 x$ fertilization results shown in parentheses

11 - Early (May) and intermediate (June) clippings are late in comparison to other studies; $2 \mathrm{x}$ fertilization in parentheses

12 - Weight of spiklet decreased with clipping date

13 - Increased at 1 site, no effect at another; results are for no $\mathrm{N}$ addition

14 - No effect on panicle $\mathrm{m}^{-2}$; spikes panicle ${ }^{-1}$ shown in parentheses

15 - Results shown for moderate intensity; severe cutting decreased seed production in all treatments

16 - Effect on tiller number in parentheses

17 - Their first defoliation treatment (May 30) was intermediate in relation to other defoliation treatments

18 - No effect of intermediate treatment (late may) on reproductive tiller density in year 1, negative effects in year 2 because tiller elongation had begun; seed yields shown in parentheses

19 - Intermediate treatment cut in June and August, late treatment cut in June, August and September

20 - No significant differences, but the author interpreted the continuous increase in total seed biomass of clipped plants as trend towards increased production. Results of fertilization shown in parentheses

21 - Results shown for normal year; all results were negative for drought year

22 - Year 2 in parentheses

23 - Extended grazing in parentheses, includes intermediate and late grazing

24 - Different varieties: T.s. subterraneum cv. Karridale, var. brachycalycinum cv. Clare, var. yanninicum cv. Trikkala

25 - No early treatment applied; parentheses show results of severe defoliation

26 - Results are for $1 / 4$ defoliation; results for $1 / 2$ defoliation are shown in parentheses

27 - Results are for $1 / 2$ defoliation; $3 / 4$ defoliation shown in parentheses; complete defoliation reduced reproductive biomass in all treatments

28 - Associated with species compositional changes

29 - All species had begun to flower when defoliation was initiated

30 - Different hybrids of Elymus lanceolatus ssp. wawawaaiensis (Scribner \& Gould) J.R. Carlson \& D. R. Dewey and E. 1. ssp. lanceolatus (Scribner \& J. G. Smith) Gould

31 - Results for different frequency treatments; only fall recovery defoliation increased flowering

32 - Experiment conducted on seedlings; data are for intermediate densities, low density reported in parentheses

33 - Results are for seed production, effect on time to flower reported in parentheses

34 - Data are for flowers plant ${ }^{-1}$ in second season when cut to $6 \mathrm{~cm}$, data for plants cut to $3 \mathrm{~cm}$ in parentheses

35 - Grown from ramets rather than seeds 
36 - Result is for entire reproductive tiller (stem + flowers); clipped plants did not flower

37 - Effects for survival of reproductive plants after clipping, results for spikelet number per reproductive plant shown in parentheses; see paper for nomenclature

38 - Results of clipping shown in parentheses

39 - Results are for low, moderate, and high intensity treatments

40 - Increased the number of basal rosettes

41 - Results depended on size; results for small plants shown in parentheses

42 - Beetles reduced seed production but aphids (in parentheses) had no effect

43 - Results are for grazing by cattle; results for bison grazing shown in parentheses

44 - Increase in the number of stems capable of reproducing

45 - Results were density dependent; high density treatment shown in parentheses

46 - Results of proportion of plants flowering shown in parentheses

47 - Results of the removal of old portions of leaves shown in parentheses

48 - Defoliation at anthesis; no effect on seed number, negative result on seed pod weight shown in parentheses

49 - Autumn defoliation; controls produced very little reproductive biomass so results are difficult to interpret

50 - Continuous defoliation decreased reproductive biomass

$51-3$ intensities and 2 frequencies all reduced pod output; effects of irrigating shown in parentheses

52 - Results are for clipping branches; results of defoliation given in parentheses

53 - No effects on seed number; effects on seed mass and complete defoliation shown in parentheses

54 - Effects on flower removal shown in parentheses

55 - Result is for $25 \%$ defoliation; effects of $100 \%$ defoliation shown in parentheses. 